przedzone wieloma dyskusjami. W wyniku porozumienia konwent podjął decyzję większością głosów o sprzedaży gruntów klasztornych na tzw. Wadzyniu, bądź sprzedaży folwarku Raciborzany. Uzyskanie kwoty ze sprzedaży było przeznaczone na poczynienie wstępnych inwestycji zabezpieczających zniszczony obiekt pocysterski w Wistyczach, jak też zabezpieczenie skromnego bytu mającego sie udać do Wistyczy, zakonnika szczyrzyckiego. Istotną kwestią było poparcie biskupa ordynariusza diecezji pińskiej, Kazimierza Bukraby, który, jak wynika $\mathrm{z}$ treści przytaczanych dokumentów, był zainteresowany ratowaniem pocysterskiego zespołu klasztornego w Wistyczach i sprowadzeniem Cystersów szczyrzyckich. Wydelegowanym zakonnikiem z ramienia opata Magiery został doświadczony duszpasterz szczyrzycki, Dominik Jurkowski, który w latach 1928-1934 był proboszczem w Górze św. Jana ${ }^{22}$ oraz ekspozytem w Krasnem, zaś nieco wcześniej bo w 1924 roku z polecenia generała zakonu, o. Kasjana został mianowany przez opata Magierę tymczasowym komisarzem w Mogile, dla zaprowadzenie „właściwego porządku” w tamtejszym klasztorze ${ }^{23}$.

$\mathrm{Z}$ dużym prawdopodobieństwem można domniemywać, iż sprawa przejęcia Wistyczy przez opactwo szczyrzyckie w 1936 roku była $\mathrm{z}$ wielu powodów bardzo skomplikowana, nie wyłączając w głównej mierze czynników ekonomicznych Nie ma niestety potwierdzenia dalszych działań konwentu w zachowanym zespole Archiwum klasztoru szczyrzyckiego. Wraz ze śmiercią opata Teodora Magiery (21 I 1937 roku), głównego orędownika przejęcia i ocalenia pocysterskich Wistyczy w odległej od Małopolski diecezji pińskiej zdaje się mieć swój koniec. Kolejny, 45 - opat klasztoru szczyrzyckiego Benedykt Bronisław Biros (1937-1956) udał się do diecezji pińskiej z zamiarem zapoznania się ze stanem faktycznym dawnego kościoła i klasztoru pocysterskiego w Wistyczach. Niestety w klasztornych dokumentach nie ma jakiejkolwiek wzmianki o podjęciu dalszych działań w tej sprawie. Widocznym „śladem” łączącym oba odległe od siebie klasztory cysterskie, jest XVII -wieczny obraz z wizerunkiem Madonny z Dzieciątkiem w stylu bizantyjskim, który w 1938 roku przywiózł do opactwa w Szczyrzycu, opat Benedykt Biros, ratując bezcenne dzieło sztuki przed całkowitym zniszczeniem.

\footnotetext{
${ }^{22}$ Schematyzm Diecezji Tarnowskiej, Tarnów 1992, s. 581; 583.

${ }^{23}$ Arch. i BOCist. sygn. XXV. 515; Arch. i BOCist. sygn. XXV. 516.
}

ARCHIWA, BIBLIOTEKI

\section{ŹRÓDŁA DO DZIEJÓW CHĘCIŃSKICH KOŚCIOŁÓW W ZASOBIE ARCHIWUM PAŃSTWOWEGO W KIELCACH}

Faktem powszechnie znanym i oczywistym jest, że znakomita część źródeł do historii Kościoła katolickiego znajduje się w zasobach archiwów kościelnych: metropolitarnych, archidiecezjalnych, diecezjalnych, parafialnych czy wreszcie klasztornych $^{2}$. Nie oznacza to jednak, że materiałów pozwalających na zgłęianie tej dziedziny nauki historycznej brak w innych polskich archiwach. Truizmem byłoby twierdzić w tym miejscu, że historyk badający dzieje Kościoła, nie może poprzestawać jedynie na wykorzystaniu materiałów pochodzacych z archiwów kościelnych, a winien uwzględnić także zasób poszczególnych archiwów państwowych. Zamiast tego warto dokonać swoistej egzemplifikacji - omówienia materiałów archiwalnych do dziejów konkretnego obszaru, znajdujących się w konkretnym archiwum. Za tego rodzaju przykład piszacemu te słowa posłużyło miasto Chęciny oraz Archiwum Państwowe w Kielcach. Niniejszy artykuł stanowi, zatem próbę odpowiedzi na pytanie, jakich źródeł badacz historii chęciń skich kościołów może spodziewać się w zasobie wyżej wymienionego archiwum.

Zamierzeniem autora jest prezentacja, usystematyzowanie i omówienie tych materiałów archiwalnych znajdujących się w zasobie Archiwum Państwowego w Kielcach, które mogą służyć badaniu dziejów Kościoła katolickiego na obszarze miasta Chęcin. Podkreślić już na wstępie należy, że Autor dokonując przeglądu źródeł nie rości sobie pretensji do uznania pracy za pełną i definitywną anali-

* Hubert Mazur - mgr historii, starszy archiwista w Archiwum Państwowym w Kielcach

${ }^{1}$ Artykuł ten powstał na bazie pracy dyplomowej: H. Mazur, Źródła do dziejów Chęcin w zasobie Archiwum Państwowego w Kielcach, Lublin 2009, napisanej na seminarium prof. dr hab. Krzysztofa Skupieńskiego, która przechowywana jest w Archiwum Uniwersytetu Marii Curie-Skłodowskiej w Lublinie oraz referatu: H. Mazur, Materialy do dziejów Chẹcin w zasobie Archiwum Państwowego w Kielcach, Kielce 2009, przechowywanego w zbiorze referatów Archiwum Państwowego w Kielcach.

${ }^{2}$ Zob. przede wszystkim: H. E. Wyczawski, Wprowadzenie do studiów w archiwach kościelnych, Kalwaria Zebrzydowska 1989 
zę materiałów archiwalnych. Jasną jest bowiem rzeczą, że ze względu na obszerność i wielogatunkowość archiwaliów stanowiacych zasób Archiwum Państwowego w Kielcach, niniejsza publikacja nie wyczerpuje do końca tematu. Wskazywać natomiast może kierunki, w jakich mogą być prowadzone potencjalne poszukiwania.

Jeśli chodzi o ramy chronologiczne artykułu, to wyznaczaja je najstarsze i najmłodsze dokumenty dotyczące dziejów chęcińskich kościołów, a pochodzące z zasobu Archiwum Państwowego w Kielcach. Są to zatem daty 1530-1990.

Podstawą niniejszej publikacji stała sie wnikliwa i długotrwała kwerenda w ponad 40 zespołach archiwalnych wchodzących w skład zasobu Archiwum Państwowego w Kielcach. Pierwszy etap poszukiwań objął pomoce archiwalne: inwentarze, spisy zdawczo-odbiorcze oraz indeksy poszczególnych zespołów archiwalnych, a także elektroniczne bazy danych SEZAM ${ }^{3}$ i IZA ${ }^{4}$. Dalszą kwerendę prowadzono już w konkretnych jednostkach archiwalnych.

Dzieje Chęcin nie doczekały sie jak dotad pełnego, wyczerpujacego i nowoczesnego opracowania ${ }^{5}$. Podobną uwagę odnieść należy do chęcińskiej parafii oraz znajdujących się na obszarze miasta kościołów ${ }^{6}$. Poszczególni autorzy ograniczyli swe badania bądź do podania ogólnych informacji o historii światyń w Chęcinach, bądź skupili się na dziejach jednej z nich w konkretnym okresie historycznym. I tak Wiktor Zapart i Małgorzata Karkocha omówili historię parafii Chęciny do 1815 r., szczególną uwagę poświęcając wystrojowi kościoła i jego wyposażeniu?. Marian Paulewicz naszkicował ogólnie rys historyczny checińskich kościołów i kaplic ${ }^{8}$. W kręgu zainteresowań Lecha Karłowicza znalazły sie natomiast dzieje klasztoru franciszkanów w Chęcinach, ze szczególnym uwzględnieniem starań o rewindykację zabudowań zakonnych ${ }^{9}$.

Przed rozpoczęciem omawiania źródeł, które mogą stanowić podstawę badań nad historią Kościoła katolickiego na terenie Chęcin warto pokrótce przybliżyć dzieje chęcińskich świątyń, a więc pierwotnego kościoła farnego św. Stanisława,

\footnotetext{
${ }^{3}$ http://baza.archiwa.gov.pl/sezam/sezam.php

${ }^{4}$ http://baza.archiwa.gov.pl/sezam/iza.php
}

${ }^{5}$ Luki tej nie wypełniają ani pozycje archaiczne: W. Grzeliński, Monografia Checin, Kielce 1908; M. Rawita-Witanowski, Dawny powiat chęciński, Kielce 2001; ani dwa wydawnictwa zbiorowe zawierające artykuły dotyczące wybranych aspektów dziejów miasta: VII wieków Chęcin. Materialy z sesji naukowej 24 lipca 1975 r., red. Z. Guldon, Kielce 1976; Chęciny. Studia z dziejów miasta XVI-XX w., red. S. Wiech, Kielce 1997; ani tym bardziej popularnonaukowa praca $W$ królewskich Checinach, red. E. Kosik, R. Nadgowski, Kielce 1996 jak również znajdujacy sie w serwisie Miasta w dokumencie archiwalnym na portalu polska.pl artykuł: H. Mazur, Chęciny dawniej, http:// checiny.polska.pl/miastodawniej/index,Checiny,cid,314659.htm

${ }^{6}$ Charakter ogólny i wprowadzający może mieć hasło: Chęciny, w: Encyklopedia katolicka, t. 3, red. R. Lukaszyk, Lublin 1979.

${ }^{7}$ W. Zapart, M. Karkocha, Dzieje parafii Checiny do 1815 r. Kielce 2007.

${ }^{8}$ M. Paulewicz, Kościoły i kaplice Chẹcin, „Nasza Przeszłość”, 57 (1982) s. 211-231.

${ }^{9}$ L. Karłowicz, Aby sprawiedliwości stalo się zadość. Opowieść o klasztorze oo. Franciszkanów w Chęcinach, Lublin 1994; L. Karłowicz, Powrócili po latach. Opowieść o kościele i klasztorze ojców franciszkanów w Chẹcinach, Kraków 1997; zob. także Dzieje konwentu franciszkańskiego w Chęcinach, Checiny 1994. kościoła parafialnego św. Bartłomieja, kościoła szpitalnego św. Ducha, nieistniejącego obecnie kościoła św. Jakuba oraz dwóch kościołów klasztornych: Wniebowzięcia Najświętszej Marii Panny oraz św. Marii Magdaleny, a także kilku kaplic.

Najstarszym ośrodkiem oddziaływania kościoła katolickiego na omawianym obszarze była świątynia położona we wsi Chęciny, (późniejsze Stare Chęciny). Ubóstwo źródeł nie pozwala na określenie dokładnej daty jej ufundowania . Prawdopodobnie nastapiło to $\mathrm{w}$ drugiej połowie XIII w. Na te date powstania kościoła wskazywałoby wezwanie św. Stanisława, które otrzymał ${ }^{10}$. Prawdopodobnie w tym samym czasie powstała przy nim parafia. Nieznane jest nazwisko fundatora starochęcińskiej świątyni. Mógł być nim właściciel wsi Mikulon" ${ }^{11}$ Parafię w Starochęcinach zlikwidowano w początkach XVI w. włączając ją do parafii Chęciny ${ }^{12}$. Przy kościele św. Stanisława w Starochęcinach ustanowiono wikariusza manualnego, reprezentującego proboszcza parafii św. Bartłomieja ${ }^{13}$. Pierwotna świątynia wzniesiona $\mathrm{z}$ drzewa modrzewiowego przetrwała do XVII wieku, kiedy to została zniszczona przez wojska szwedzkie ${ }^{14}$. Nowy murowany kościół w stylu barokowym wzniósł w latach 1680-1690 starosta Stanisław Bidziński ${ }^{15}$. Został on zrujnowany w XVIII w., a nastepnie odnowiony w latach czterdziestych XIX stulecia. Od 1969 r. starochęcińska świątynia jest kościołem rektoralnym, spełniającym funkcje duszpasterskie dla mieszkańców Starochęcin, Lipowicy, Przymiarek i Podzamcza Chęcńskiego ${ }^{16}$.

Najprawdopodobniej w latach 1306-1325 doszło do lokacji Chęcin ${ }^{17}$, jako ośrodka położonego u stóp Góry Zamkowej. Dotychczasowa wieś Chęciny uzyskała nazwe Stare Chęciny (obecnie Starocheciny). Zapewne wraz z lokacja miasta wzniesiono murowaną, gotycką świątynię pod wezwaniem św. Bartłomieja i św. Jadwigi, której fundatorem był król Władysław Łokietek ${ }^{18}$. Pierwszy kościół miejski podlegał pierwotnie macierzystej parafii w Starochęcinach. Dopiero za rządów Kazimierza Wielkiego ewentualnie Elżbiety Łokietkówny erygowano przy nim parafię $e^{19}$. W świątyni istniało szereg ołtarzy, $\mathrm{z}$ którymi powiązane były liczne prebendy ${ }^{20}$. Parafia poza miastem obejmowała wsie: Polichno, Zgórsko i Skiby ${ }^{21}$. Po zlikwidowaniu parafii w Starochęcinach parafia w Chęcinach po-

${ }^{10}$ F. Kiryk, Chẹciny w epoce piastowskiej i jagiellońskiej, s. 41; Grzeliński, Monografia Chęcin, s. $44,55$.

${ }^{11}$ Paulewicz, Kościoly i kaplice, s. 212.

${ }^{12}$ Grzeliński, Monografia Checin, s. 55 .

${ }_{13}$ Paulewicz, Kościoly $i$ kaplice, s. 213.

${ }_{14}$ Zapart, Karkocha, Dzieje parafii Chęciny, s. 17.

${ }^{15}$ Katalog zabytków sztuki w Polsce, t. 3, Województwo kieleckie, z. 3 Powiat kielecki, red. J. Łoziński, B. Wolff, Warszawa 1957, s. 13-22.

${ }^{16}$ Paulewicz, Kościoly i kaplice, s. 213, 214

${ }^{17}$ Kiryk, Chęciny w epoce, s. 30

${ }^{18}$ Paulewicz, Kościoly $i$ kaplice, s. 214. Zdaniem Rawity-Witanowskiego, (Dawny powiat), s. 54, kościół pochodzi z końca XIV lub początków XV w.

${ }^{19}$ Paulewicz, Kościoly i kaplice, s. 214.

${ }^{20}$ Tamże.

${ }^{21}$ Zapart, Karkocha, Dzieje parafii Chęciny, s. 22. 
większyła się o $13 \mathrm{wsi}^{22}$. Chęcińska fara przeżywała okres rozkwitu do końca lat sześćdziesiatych XVI w., kiedy to za sprawa starosty checińskiego Stanisława Szafrańca dostała się w ręce kalwinów $w^{23}$. Miasto stało się wówczas siedzibą kalwińskiej jednostki administracji terytorialnej - dystryktu chęcińskiego ${ }^{24}$. Proboszcz zmuszony był przenieść się do kościoła św. Ducha ${ }^{25}$. Rekatolizacja światyni nastapiła w 1597 r., w czym duże zasługi miał tutejszy starosta Stanisław Branicki $^{26}$. Po odnowieniu zniszczonego kościoła, w 1603 r. nastapiła jego ponowna konsekracja ${ }^{27}$. Dodać trzeba, że przy świątyni w poczatku XVII Kasper Fodyga ufundował kaplicę pod wezwaniem Trzech Króli ${ }^{28}$. Obecnie do parafii Św. Bartłomieja Apostoła w Chęcinach poza miastem Chęciny należą wsie: Korzecko, Mosty, Skiby, Szewce, Zawada ${ }^{29}$

Drugim obiektem sakralnym powstałym na terenie Chęcin był klasztor franciszkanów z kościołem pod wezwaniem św. Franciszka z Asyżu. Ufundował go król Kazimierz Wielki, uzyskawszy na to zgode papieża Urbana V w bulli z dnia 5 marca $1367 \mathrm{r}^{30}$ Około $1580 \mathrm{r}$. kościół klasztorny zajęli kalwini. Świątynię i klasztor udało się odzyskać katolikom w roku $1603^{31}$. Po 1605 r. kościół sumptem starosty Stanisława Branickiego został odnowiony, a klasztor także rozbudowany. Świątynię w $1628 \mathrm{r}$. ponownie konsekrowano. Uzyskała wówczas nowe wezwanie - Wniebowzięcia Najświętszej Marii Panny. W 1640 r. przy kościele wzniesiono kaplicę grobową Branickich ${ }^{32}$. W 1657 r. klasztor został ponownie zniszczony, tym razem wskuteknajazdu wojsk księcia Rakoczego. Staraniemikosztem starosty Stefana Bidzińskiego kościół i klasztor w 1668 r. zostały odbudowane. Największym ciosem dla checińskich franciszkanów była kasata ich klasztoru w $1817 \mathrm{r}$. i przejęcia majątku przez państwo ${ }^{33}$. Odebrane franciszkanom budynki przeznaczono na więzienie. W ramach prac adaptacyjnych w oknach obiektu wstawiono kraty, drzwi obito blachą, nawę kościoła przepołowiono stropem na dwie części. Całość otoczono wysokim kamiennym murem. Wiezienie chęcińskie ze względu na specyfikę budynku (wilgoć, małe okna, panujący półmrok) należało do kategorii ciężkich. Przetrzymywano tu przede wszystkim więźniów politycznych, zwłaszcza w okresie po powstaniu listopadowym, styczniowym, rewolucji 1905 roku oraz w czasach I wojny światowej. Więzienie zostało utrzy-

\footnotetext{
${ }^{22}$ Tamże, s. 32.
}

${ }^{23}$ Według tradycji i niektórych opracowań (Grzeliński, Monografia, s. 41) kalwini mieli rzekomo oddać chęcińskie kościoły arianom. Poglądy te zostały odrzucone przez W. Urbana, Reformacja w Chęcinach, s. 100.

${ }^{24}$ Urban, Reformacja w Chęcinach, s. 101.

${ }^{25}$ Grzeliński, Monografia Chẹcin, s. 40, 41.

${ }^{26}$ Tamże; Zapart, Karkocha, Dzieje parafii Chęciny, s. 53.

${ }^{27}$ Paulewicz, Kościoly $i$ kaplice, s. 215.

${ }^{28}$ Tamże, s. 229-231.

${ }^{29}$ Katalog duchowieństwa diecezji kieleckiej, oprac. D. Olszewski, Kielce 1999, s. 180.

${ }^{30}$ Tamże, s. 217.

${ }^{31}$ Urban, Reformacja w Checinach, s. 101

${ }^{32}$ Katalog zabytków, s. 15.

${ }^{33}$ Paulewicz, Kościoly i kaplice, s. 219. mane w dwudziestoleciu miedzywojennym. Obiekt nie posiadając centralnego ogrzewania, kanalizacji, elektryczności i bieżącej wody cieszył się złą sławą. Umieszczano tu wówczas głównie działaczy komunistycznych. 30 listopada 1927 r. pod naciskiem społeczeństwa, Ministerstwo Sprawiedliwości zlikwidowało Więzienie Karne w Chęcinach ${ }^{34}$. W poklasztornych murach umieszczono szkołę, sąd grodzki, oraz świetlicę oddziału Związku Strzeleckiego. Po wojnie omawiane budynki zajmowała szkoła kamieniarska (do 1948 r.), nasteppnie Zakłady Miessne, Spółdzielnia Pracy „Twórczość”. W latach 1968-1972 przeprowadzono odbudowę zniszczonego kompleksu pofranciszkańskiego. Wszystkie budynki pozbawiono charakteru sakralnego - zdjęto krzyże, zniszczono ołtarze, zasypano krypty. Po zakończeniu prac remontowych obiekt został przekazany Wojewódzkiemu Przedsiębiorstwu Turystycznemu „Łysogóry” w Kielcach. W budynkach klasztornych urzadzono hotel, kościół przeznaczono na restauracje, reszta kompleksu stanowić miała schronisko turystyczne. Od 1980 r. franciszkanie konwentualni rozpoczęli starania zarówno o rewindykację kompleksu klasztornego, jak również o przywrócenie pierwotnej jego funkcji. Dzięki intensywnie prowadzonym działaniom zakonnicy odzyskali własność w $1991 \mathrm{r}^{35}$

Niewątpliwie najmniej znaną świątynią Chęcin jest nieistniejący już drewniany kościół pod wezwaniem św. Jakuba. Znajdował się on w granicach posiadłości franciszkanów. Nieznana jest dokładna data powstania świątyni, prawdopodobnie nastapiło to w XIV w. Nie wiadomo także, kto był jej fundatorem. Być może obiekt ten miał charakter elitarny i służył jako miejsce nabożeństw dla chęcińskich górników. Kościół św. Jakuba w Chęcinach został zniszczony w okresie potopu szwedzkiego ${ }^{36}$.

Fundacje kościoła szpitalnego pod wezwaniem Wniebowzięcia Najświętszej Marii Panny datować zapewne należy na przełom XIV i XV wieku. Został on usytuowany według klasycznych wzorów dla budynków szpitalnych poza ścisłą zabudowa miejska, przy trakcie do Małogoszcza. W XVI stuleciu w miejscu dotychczasowej, wzniesiono nową znacznie obszerniejszą świątynię, która uzyskała wezwanie św. Ducha. Kościół erygowano w 1569 r. W okresie reformacji, wskutek zajecia przez kalwinów fary miejskiej, w kościele św. Ducha osiadł proboszcz parafii Chęciny. Tym samym omawiana świątynia przez około 30 lat pełniła funkcję kościoła parafialnego. Rekatolizacja kościoła św. Bartłomieja i powrót doń parafii w poczatkach XVII w. sprawiły, że świątynia św. Ducha opustoszała i zaczęła popadać w ruinę. Dzięki wójtowi chęcińskiemu i muratorowi Kasprowi Fodydze przeprowadzono jej restaurację. Po sprowadzeniu do Chęcin klarysek, które przejeły kościół św. Marii Magdaleny, do światyni św. Ducha w 1673 r. powrócił proboszcz szpitalny. W pierwszej połowie XIX w. budynek kościelny został przejęty przez władze carskie, gdzie w 1820 r. ulokowano Sąd Policji Po-

${ }^{34}$ R. Deparasiński, K. Urbański, Więzienie chęcińskie w latach 1919-1927, w: VII wieków, s. $123-134$.

${ }^{35}$ Karłowicz, Aby sprawiedliwości, passim; Tenże, Powrócili po latach, passim.

${ }^{36}$ Paulewicz, Kościoty, s. 220, 221 

prawczej. Później został on przekazany w ręce prywatne ${ }^{37}$, w których pozostaje
do chwili obecnej.

Najprawdopodobniej w połowie XVI w. z fundacji burmistrza i rajców miejskich powstał kościół pod wezwaniem św. Marii Magdaleny w Checinach. Zapewne przy światyni funkcjonował dom gościnny. W okresie reformacji, gdy kościoły parafialny i franciszkański zajęte zostały przez kalwinów, świątynia św. Ducha stała się kościołem parafialnym. W związku z powyższym miasto zdecydowało się oddać proboszczowi szpitalnemu świątynię św. Marii Magdaleny. Na ponad sto lat kościół ten stał się kościołem szpitalnym. W poczatkach XVII stulecia w sąsiedztwie świątyni Kasper Fodyga wójt Chęcin, murator, rzeźbiarz i gwarek chęciński w jednej osobie wzniósł piętrowy dom, przeznaczając go w testamencie na cele pobożne. Jego bratanek ks. Henryk Fodyga wypełniając ostatnią wolę zmarłego w 1643 r. przekazał nieruchomość klaryskom sprowadzonym do Chęcin z Gniezna. Panny franciszkanki, jak zwano klaryski, rozpoczęły starania o przejęcie kościoła św. Marii Magdaleny, zakończone sukcesem w 1673 roku. Swiątynię sumptem starosty Stefana Bidzińskiego (ojca ksieni Teresy Bidzińskiej) znacznie rozszerzono, łącząc ją także z rozbudowanym klasztorem. Ponadto dokupiono ogród, a całość założenia otoczono murem. Władze carskie na przełomie XIX i XX wieku zabroniły przyjmowania nowicjuszek do chęcińskiego klasztoru sióstr klarysek, doprowadzając tym samym niemal do „wymarcia" zgromadzenia. W 1902 r. klasztor ostatecznie zamknięto, a pozostałe przy życiu zakonnice przeniesiono do św. Katarzyny. Po prawie 30 latach opuszczenia, w 1930 r. w klasztorze osiadły bernardynki z Wilna ${ }^{38}$. Władze PRL czyniły zakonnicom szereg trudności w związku z dzierżawą budynku. Mimo to bernardynkom udało się utrzymać kościół i klasztor, który w ich rękach pozostaje do chwili obecnej.

Oprócz kościołów w Chęcinach istniało kilka kaplic. Najstarszą z nich była kaplica zamkowa pod wezwaniem Dziesięciu tysięcy św. żołnierzy wojowników. Jej losy były ściśle związane z dziejami chęcińskiej warowni. Toteż gdy zamek zaczął popadać $w$ ruinę wraz z nim zniszczeniu uległa kaplica ${ }^{39}$. Przy klasztorze franciszkanów funkcjonowała z kolei kaplica św. Leonarda, która wzniesiono prawdopodobnie w połowie XVI w. W XVII stuleciu rozbudowany obiekt otrzymał ostateczny barokowy kształt architektoniczny. Po kasacie klasztoru w $1817 \mathrm{r}$. opuszczony przez franciszkanów gmach zaadaptowano na cele więzienia. Jedynie kaplica św. Leonarda nadal spełniała swe funkcje sakralne, jako miejsce modlitwy przeznaczone dla więźniów. Stan ten utrzymał się do $1927 \mathrm{r}$. W latach okupacji hitlerowskiej w kaplicy odbywały się nabożeństwa dla żołnierzy Luftwaffe. Po wojnie omawiany obiekt wraz z całym gmachem klasztornym przechodził zmienne koleje losu. Na przełomie lat sześćdziesiątych i siedemdziesiątych przeprowadzono remont zabudowań pofranciszkańskich przeznaczając je na hotel i restaurację. W kaplicy natomiast umieszczono coctailbar. Kaplica wraz z całym klasztorem powróciła do rąk prawowitych właścicieli, czyli franciszkanów 17

\footnotetext{
${ }^{37}$ Tamże, s. 222-225

${ }^{38}$ Tamże, s. 225-227.

${ }^{39}$ Tamże, s. 227,228
}

kwietnia $1991 \mathrm{r}^{40} \mathrm{~W}$ latach 1965-1970 wzniesiono także kaplicę cmentarną na powstałej w 1807 r. nekropolii41

Warto jeszcze kilka zdań poświęcić przynależności administracyjnej parafii Chęciny. Przez cały okres przedrozbiorowy należała ona do archidiakonatu kurzelowskiego będącego częścią archidiecezji gnieźnieńskiej². Prawdopodobnie w drugiej połowie XVI w. w ramach archidiakonatu kurzelowskiego nastapił podział na dekanaty. Parafia Chęciny weszła wówczas w skład dekanatu małogoskiego ${ }^{43}$. Stan ten utrzymał się do początku okresu rozbiorowego. Przypadły Austrii w wyniku III rozbioru archidiakonat kurzelowski początkowo znajdował się pod jurysdykcją arcybiskupa gnieźnieńskiego, po czym w 1800 r. przeszedł pod jurysdykcję biskupa krakowskiego. Znacznie większe zmiany nastały w 1807 r., kiedy to parafia Chęciny znalazła się w nowo utworzonej diecezji kieleckiej. Początkowo utrzymany został dotychczasowy podział na dekanaty i archidiakonaty. W latach 1808-1809 bp kielecki Górski przeprowadził reformę administracyjna, która polegała na zniesieniu archidiakonatów i reorganizacji sieci dekanalnej. Powołano wówczas do życia dekanat chęciński. Rezultatem kolejnych zmian politycznych było zniesienie diecezji kieleckiej w 1818 r. Dekanat chęciński wraz sześcioma innymi dekanatami włączono w 1819 r. do diecezji krakowskiej ${ }^{44}$. Rok później został on skasowany, a parafia Chęciny znalazła się w dekanacie kieleckim $^{45}$. Od czasów reaktywacji diecezji kieleckiej w 1883 r. parafia Chęciny niezmiennie do chwili obecnej leży w jej granicach ${ }^{46}$. Natomiast w $1958 \mathrm{r}$. Chęciny stały się ponownie siedzibą dekanatu ${ }^{47}$.

Przechodząc do zasadniczej części niniejszego artykułu wyjaśnić trzeba, że przeglądu źródeł dokonano przyjmując ich podział według kryterium przynależności zespołowej. W pierwszej kolejności omówiono akta organów administracji ogólnej w porządku instancyjno-chronologicznym, następnie dokumentację wytworzoną przez instytucje administracji specjalnej, na końcu zaś archiwalia wytworzone przez pozostałych aktotwórców. Autor zasygnalizował także zespoły archiwalne dotyczące dziejów związanych z kościołem instytucji, a więc szkół i przytułków. Analizę materiałów archiwalnych wchodzących w skład danego zespołu, poprzedzono krótką jego charakterystyką. Auto starał się omówić

${ }^{40}$ Tamże, s. 228, 229; Karłowicz, Aby sprawiedliwości, passim; Tenże, Powrócili po latach, passim.

${ }^{41}$ Paulewicz, Kościoly i kaplice, s. 231

${ }^{42} \mathrm{~J} a n a$ Easkiego arcybiskupa gnieźnieńskiego, prymasa, legata urodzonego Liber Beneficiorum archidiecezyi gnieźnieńskiej, wyd. ks. J. Łukowski, t. 1, Gniezno 1880, s. 584.

${ }^{43}$ W. Müller, Dzieje kościola w XVI-XVIII wieku na obszarze dzisiejszej diecezji kieleckiej, w: Ksiega Jubileuszu Stulecia Diecezji Kieleckiej (1883-1893), Kielce 1986, s. 221, 225.

${ }^{44}$ B. Kumor, Organizacja terytorialna diecezji kieleckiej, „Nasza Przeszłość 27 (1963) s. 191216.

${ }^{45}$ Tenże, Ustrój $i$ organizacja Kościola polskiego w latach niewoli narodowej (1772-1918), Kraków 1980, s. 560.

${ }^{46}$ L. Müllerowa, Organizacja terytorialna diecezji kieleckiej w latach 1883-1983, s. 279-280 ${ }^{47}$ T. Wróbel, Zarys historii diecezji kieleckiej, „Kielecki Przegląd Diecezjalny”, 5 (1982) 
w skrócie dzieje konkretnego aktotwórcy, strukturę wewnętrzną zespołu, jego rozmiar (w jednostkach archiwalnych) oraz daty skrajne.

\section{Rząd Gubernialny Radomski}

Bodaj najważniejszym źródłem do badań nad historią regionu między Wisłą a Pilica w pierwszej połowie XIX w. jest znajdujący się w zasobie Archiwum Państwowego w Kielcach zespół Rząd Gubernialny Radomski ${ }^{48}$. Jest to zespół złożony, który powstał w wyniku działalności kancelarii kilku urzędów administracji państwowej funkcjonujących na omawianym terenie w latach 1795-1866. Po upadku I Rzeczpospolitej dawny obszar województwa sandomierskiego i krakowskiego znalazł się pod okupacją austriacką i wszedł w skład Galicji Zachodniej. Austriacy zlikwidowali dotychczasowy podział na województwa i powiaty, wprowadzając własny oparty na cyrkułach. Tym samym przestał istnieć powiat chęciński, a na siedzibę cyrkułu wyznaczono Kielce. W 1803 r. cyrkuł kielecki podzielono na trzy okręgi: kielecki, stopnicki i opoczyński. Do kompetencji urzędów cyrkularnych należały nadzór nad ruchem ludności, sprawy statystyczne wojskowe, polityczne, ekonomiczne i skarbowe. Na mocy traktatu w Schönbrunn z 14 października 1809 r. Galicja zachodnia znalazła sie w granicach Ksiestwa Warszawskiego. Od 1810 r. zaprowadzono na tych terenach nową organizację. Utworzono wówczas dwa departamenty krakowski i radomski. Ten ostatni składał się z 10 powiatów, a jednym z nich był powiat kielecki. Na czele departamentu stał prefekt, który sprawował ogólny nadzór nad administracją, sprawami oświaty i nauczania, skarbowymi, policyjnymi, gospodarczymi i zdrowotnymi, porządkiem i bezpieczeństwem departamentu. Identyczną władzę na terenie powiatu sprawował podprefekt. Po zniesieniu Księstwa Warszawskiego omawiany obszar włączono w granice Królestwa Polskiego. Postanowieniem namiestnika z 16 stycznia 1816 r. wprowadzono podział Królestwa Polskiego na województwa. Powstały wówczas min. województwa sandomierskie i krakowskie. Na stolicę tego ostatniego obrano Kielce. Na czele każdego województwa stała Komisja Wojewódzka, do której zadań należało min. wykonywanie rozporządzeń komisji rządowych, czuwanie nad porządkiem wewnętrznym i bezpieczeństwem mieszkańców, opieka nad własnością publiczną i oświata. Województwo krakowskie podzielono na cztery obwody, te zaś składały się z powiatów. Ukazem carskim z 7 marca 1837 r. województwa przemianowano na gubernie, komisje wojewódzkie zaś na rządy gubernialne. Tym samym województwo krakowskie zastapiła gubernia krakowska z siedzibą w Kielcach, a Komisję Województwa Krakowskiego Rząd Gubernialny Krakowski. W czerwcu 1841 r. nazwe guberni krakowskiej zmieniono na kielecką, powołując jednocześnie Rząd Gubernialny Kielecki. W stycznia 1845 r. nastapiło połączenie guberni kieleckiej i sandomierskiej,

${ }^{48}$ Zaznaczyć należy, że druga część omawianego zespołu znajduje się w zasobie Archiwum Państwowego w Radomiu. w wyniku czego powstała gubernia radomska z Rządem Gubernialnym Radomskim na czele ${ }^{49}$.

W skład powstałego w skutek omówionych wyżej przeobrażeń administracyjnych zespołu Rząd Gubernialny Radomski wchodza akta wytworzone przez następujące urzędy administracji ogólnej: Krakowski Urząd Cyrkularny (18071809), Radomski Urząd Cyrkularny (1807-1809), Prefekt Departamentu Krakowskiego (1810-1816), Prefekt Departamentu Radomskiego (1810-1816), Komisja Województwa Krakowskiego (1816-1837), Komisja Województwa Sandomierskiego (1816-1837), Rząd Gubernialny Krakowski (1837-1841), Rzad Gubernialny Kielecki (1841-1844), Rząd Gubernialny Sandomierski (1837-1844), Rząd Gubernialny Radomski (1845-1866). Zespół składa się z akt następujących Wydziałów: Służby Ogólnej, Administracyjnego (Sekcje: Administracyjna, Wyznań, Rachuby, Prawna, Ubezpieczeń, Komunikacji), Skarbowego, i Wojskowo-Policyjnego ${ }^{50}$. Zespół Rząd Gubernialny Radomski liczy blisko 9000 jednostek archiwalnych, a jego granice chronologiczne to lata [1789] 1807-1866 [1886].

Rząd Gubernialny Radomski stanowi nieocenioną podstawę źródłową do badań nad dziejami Chęcin w okresie 1 połowy XIX w. Dla poznania historii chęcińskich kościołów w tym okresie znaczenie fundamentalne mają akta znajdujące się w Sekcji Wyznaniowej Wydziału Administracyjnego.

Najwięcej, bo aż trzy jednostki w omawianym zespole, dotyczą spraw remontu parafialnej świątyni. Najstarsza z nich pochodzi z lat 1811-1815 i zawiera korespondencję w sprawach reparacji kościoła pomiędzy proboszczem, a prefektem departamentu radomskiego i podprefektem powiatu kieleckiego $0^{51}$. Znaleźć w niej można także: rachunki wydatków prywatnych proboszcza Checińskiego na reparację kościoła z lat 1792-1811 ${ }^{52}$, wyszczególnienie ekspensy (wydatków) na reparację kościoła ${ }^{53}$, ,rozkład na reparacje kościoła i szkoły w Chẹcinach cyrkułu kieleckiego potrzebnych kosztów okazujący w jakiej ilości niżej wyrażone dwory, miasta i wsie do ich złożenia w gotowych pieniądzach i robociźnie przyłożyć się mają ${ }^{54}$, wyciąg wsiów, ludności i stanu bydła do parafii Checińskiej powiatu kieleckiego i departamentu radomskiego należących"ss, czy w końcu Rozporządzenie C. K. Pełnomocnej Komisji Zadwornej na Galicję Zachodnią z 10 października 1800 r. „Ile państwa, kollator, wcielone do parafii gromady, i proboszcze przykładać się mają do budowania kościołów, probostw i szkół i jak im sobie postapić należy względem obrachunków budowniczych"s6. Warto nadmienić, że

${ }^{49} \mathrm{~J}$. Swajdo, Między Wistą a Pilica. Dzieje podziałów administracyjnych w regionie kieleckoradomskim do 1975 roku, Kielce 2005, s. 13-18.

${ }^{50}$ Szerzej zob. Wstep do inwentarza zespotu akt Rzad Gubernialny Radomski 1807-1866 [1892], oprac. R. Guldon, E. Wirska, Kielce 1971; Archiwum Państwowe w Kielcach i jego oddziaty. Przewodnik po zasobie archiwalnym, red. S. Marcinkowski, Warszawa-Łódź 1993, s. 51, 52.

${ }^{51}$ Archiwum Państwowe w Kielcach (dalej: APK), Rząd Gubernialny Radomski, sygn. 5563.

${ }^{52}$ Tamże, s. 19-23.

${ }^{53}$ Tamże, s. 30, 38.

${ }^{54}$ Tamże, s. 82.

${ }^{55}$ Tamże, s. 8.

${ }^{56}$ Tamże, s. 41-47. 
dokumenty w omawianej jednostce spisane są w języku polskim i języku niemieckim.

Dwa poszyty stanowią dokumentację dotyczącą zasklepienia jaskini, jaka powstała pod kościołem parafialnym w $1838 \mathrm{r}$. wskutek prowadzonych na stoku wzgórza prac górniczych. W jednostkach tych przeważa korespondencja w przedmiotowej sprawie pomiędzy władzami kościelnymi (Dozór kościoła parafialnego w Chęcinach, Konsystorz Generalny Diecezji Krakowskiej, Administrator Generalny Diecezji Krakowskiej) a organami administracji państwowej (min. Komisja Rządowa Spraw Wewnętrznych i Duchownych, Rząd Gubernialny Krakowski, Rząd Gubernialny Kielecki, Komisarz Obwodu Kieleckiego, Naczelnik Powiatu Kieleckiego, Burmistrz miasta Chęcin, Inżynier Guberni Kieleckiej, Asesor Budowniczy powiatu kieleckiego). Dość liczne są także wykazy i rozkłady kosztów, kosztorysy robót czy kwity związane z prowadzonymi pracami reparacyjnymi. Na szczególną uwagę zasługują: Protokót rewizyjno-odbiorczy zasklepionej jaskini pod kościolem parafialnym powstatej (zawiera opis chodnika, obrachunek, kosztorys oraz właściwy protokół rewizyjno-odbiorczy), Opisanie załamu, który w mieście rzqdowym Chęcinach pod parafialnym kościolem na górze zamkowej $w$ dniu 22 marca ( 3 kwietnia) 1838 r. otworzyl się oraz plan zawierający Rys poprzeczny $i$ pionowy rozpadliny $i$ zalamu, który przy kościele parafialnym $w$ mieście rządowym Chęcinach otworzyl się. Poza tym wymienić należy listy płac robotników pracujących przy zasypywaniu rozpadliny, rozkład kosztów na reparację kościoła rzymskokatolickiego w Chęcinach, protokół licytacji ołowiu wyciagniętego ze wspomnianej wyżej jaskini oraz dowody ogłoszenia licytacji na reparację kościoła parafialnego w Chęcinach z 1842, które są niczym innym jak ogłoszeniami w Dzienniku Urzędowym Guberni Kieleckiej oraz w Gazecie Rzadowej $^{57}$. W drugim poszycie odnaleźć też można protokoły posiedzenia dozoru kościelnego, protokół wyboru dozoru kościelnego z 1845 r., protokół w okoliczności rozpoznania obecnego stanu kościoła w Chęcinach z 1839 r. dokumentację dotyczącą pożyczek udzielonych przez Bank Polski na przeprowadzenie prac, protokół rewizji kościoła materiały odnośnie naprawy organów. Szczególnie interesujący jest Rysunek bocznych elewacji kościola parafialnego i dzwonnicy w mieście Chęcinach wskazujacy zarysowanie sie murów ${ }^{58}$.

W wytworzonej w latach 1820-1821 jednostce zatytułowanej Odłqczenie włościan wsi Polichno od parafii Chęcińskiej zachowała się petycja z 1820 r. wystosowana przez mieszkańców Polichna do Komisji Rządowej Wyznań Religijnych i Oświecenia Publicznego. Chłopi proszą w niej o to, by nie przyłączać wspomnianej w wsi do parafii w Bolminie, a pozostawić ja jak dotychczas przy parafii chęcińskiej ${ }^{59}$. Pozostała dokumentacja $\mathrm{w}$ tej jednostce to korespondencja pomiędzy Komisją Rządową Wyznań Religijnych i Oświecenia Publicznego, Komisarzem Obwodu Kieleckiego i Komisją Województwa Krakowskiego ${ }^{60}$.

\section{${ }^{57}$ Tamże, sygn. 5564}

${ }^{58}$ Tamże, sygn. 5565, s. 217

${ }^{59}$ Tamże, sygn. 5567 , s. 4-9

${ }^{60}$ Tamże, s. 1-3, 10-12.
W poszycie oznaczonym sygnaturą 5571 znaleźć można dane dotyczące przyparafialnych prebend w Chęcinach: Protokót komisji świecko-duchownej delegowanej do spisania funduszy duchownych dwóch prebend istniejacych przy kościele parafialnym $w$ Checinach ${ }^{61}$, Spis tabelaryczny funduszy dwóch mansjonerii w Chęcinach ${ }^{62}$, Inwentarz Fundi Instructi prebend ${ }^{63}$ oraz korespondencję dotyczące jego sporządzenia ${ }^{64}$.

Interesujące materiały takie jak inwentarze Fundi Instructi probostwa chęcińskiego $\mathrm{z}$ roku $1833^{65} \mathrm{i} 1840^{66}$ oraz spis funduszu probostwa $\mathrm{z} 1826 \mathrm{r}^{67}$ zawarte są w poszycie $z$ lat $1825-1842$. W jednostce tej ukryty jest najstarszy dokument dotyczący Chęcin. Jest to pergamin wydany w 1530 r. przez króla Zygmunta Sta$\mathrm{rego}^{68}$. Dokument dotyczy fundacji nowego ołtarza w kościele parafialnym w Chęcinach. Resztę dokumentacji stanowią akta uposażeniowe parafii i prebend, akta notarialne i mapki kościelnych gruntów oraz korespondencja Komisji Rządowej Wyznań Religijnych i Oświecenia Publicznego, Komisji Województwa Krakowskiego, Komisarza Obwodu Kieleckiego.

Na wskroś ekonomiczny charakter ma poszyt z lat 1842-1866 dotyczacy checińskiej parafii. Znajduje się tam sporo korespondencji pomiędzy: Komisją Rządową Spraw Wewnętrznych i Duchownych, Rządem Gubernialnym Radomskim, Naczelnikiem Powiatu Kieleckiego i Burmistrzem Chęcin, poświęconej zamianie gruntów należących do wikariatu chęcińskiego, zamianie gruntów probostwa, wystawieniu na licytację korali, pereł i kotła miedzianego celem uzyskania środków na renowację dwóch obrazów, a także sprawom majątkowych kościoła, jego remontom, dzierżawom ${ }^{69}$. Tu też można znaleźć wykaz gruntów i łąk należących do probostwa chęcińskiego i prebend z $1821 \mathrm{r}^{70}$, Kontrakt na wydzierżawienie probostwa chęcinskiego wraz z dwoma folwarkami wikarialnemi w mieście Checinach pomiędzy proboszczem parafii chęcinskiej z jednej strony a Konstantym Moczarskim z drugiej strony zawarty 1 czerwca 1852 r., inna korespondencje dotycząca wymienionej wyżej dzierżawy ${ }^{71}$, Spis inwentarza probostwa checińskiego przy oddaniu tegoż $w$ dzierżawe sporządzony $w$ dniu 1 czerwca $1852 \mathrm{r}^{72}$ akta notarialne i wyciągi plebańskich wykazów hipotecznych plebańskich gruntów, umowy na dzierżawę probostwa, Wykaz rocznie oplacanych podatków do

\footnotetext{
${ }^{61}$ Tamże, sygn. 5571, s. 1-8.

62 Tamże, s. 9-15.

${ }^{63}$ Tamże, s. 22-24.

${ }^{64}$ Tamże, passim.

${ }^{65}$ Tamże, sygn. 5570, s. 267-340

${ }^{66}$ Tamże, s. 488-566.

${ }^{67}$ Tamże, s. 1-21.

${ }^{68}$ Tamże, s. 51.

${ }^{69}$ Tamże, sygn. 5562, passim.

${ }^{70}$ Tamże, s. 174.

${ }^{71}$ Tamże, s. $192-199$

${ }^{72}$ Tamże, s. 179-188.
} 
kasy powiatu kieleckiego przez probostwo Chęciny ${ }^{73}$. W tym poszycie zachował się też Inwentarz Probostwa Checińskiego z $1861 \mathbf{r}^{74}$

Osobny poszyt w omawianym zespole zawiera materiały tyczące się funduszu pokładnego w parafii Checciny $z$ lat $1859-1866$. Sa to przede wszystkim wykazy tegoż funduszu z lat 1857-1861 ujete w formie tabelarycznej. Spisy te zawierają nazwiska i imiona osób zmarłych w parafii, ze wskazaniem ich zawodu ( proceder życia), miejsca zamieszkania, daty śmierci i wielkości wniesionej opłaty za pogrzeb. Resztę dokumentacji stanowią rachunki dochodu, i wydatku funduszu pokładnego z lat 1858-1865 oraz załączone do nich dowody, a także koresponden$\mathrm{cja}^{75}$.

W aktach Rządu Gubernialnego Radomskiego odnaleźć można też materiały $\mathrm{z}$ lat 1825-1827 dotyczące zamiany gruntów należących do chęcińskich franciszkanów na grunty będące własnością Wincentego Sokołowskiego (korespondencja pomiędzy Komisarzem Obwodu Kieleckiego, Komisją Województwa Krakowskiego, Konsystorzem Biskupim Kieleckim) ${ }^{76}$. W poszycie tym znajduje się Plan sytuacyjny gruntów tak $W$. Sokolowskiego dziedzicznych jako też $w$ funduszu XX. Franciszkanów Chẹcińskich należacych, które na zamiane wystawione zostaly sporzadzony przez Wincentego Zajaczkowskiego przysieglego geometrę $e^{77}$, odmowna decyzja wydana przez Komisję Rządową Wyznań Religijnych i Oświecenia Publicznego ${ }^{78}$ oraz protokół Komisji świecko-duchownej w przedmiotowej sprawie $^{79}$.

Obszerne materiały w omawianym zespole poświęcone są egzekucji procentów panien franciszkanek ${ }^{80} \mathrm{i}$ księży franciszkanów w Chęcinach ${ }^{81}$.

\section{Rząd Gubernialny Kielecki}

Efektem nowej polityki władz carskich wobec Polaków po stłumieniu powstania styczniowego, była reforma administracyjna Królestwa Polskiego. Na podstawie „Ustawy o zarządzie gubernialnym i powiatowym w guberniach Królestwa Polskiego" z 31 grudnia 1866 r. na terenie dotychczasowej guberni radomskiej powstały dwie nowe gubernie: radomska i kielecka. Organem zarządzającym gubernią kielecką został Rząd Gubernialny Kielecki z gubernatorem na czele. Rząd zajmował się sprawami administracyjno-gospodarczymi. Załatwiał problemy związane ze służbą zdrowia, ubezpieczeniem, budownictwem i drogami, zarządem: skarbowym i dóbr państwowych, zaopatrzeniem wojsk i policji,

\footnotetext{
${ }^{73}$ Tamże, passim.

${ }^{74}$ Tamże, s. 484-532.

${ }^{75}$ Tamże, sygn. 5561.

${ }^{76}$ Tamże, sygn. 5566.

${ }^{77}$ Tamże, s. 23.

${ }^{78}$ Tamże, s. 14

${ }^{79}$ Tamże, s. $18-22$

${ }^{80}$ Tamże, sygn. 5568.

${ }^{81}$ Tamże, sygn. 5569.
}

kontrolą ruchu ludności. Kompetencje swe rząd gubernialny realizował za pomocą poszczególnych wydziałów. Wynikiem licznych strukturalnych reorganizacji urzędu, jest zespół Rząd Gubernialny Kielecki złożony z dokumentacji Wydziałów: Administracyjnego, Wojskowo-Policyjnego, Prawnego, Lekarskiego, Weterynaryjnego, Budowlanego, Ubezpieczeń oraz Kancelarii Prezydialnej. Dodać warto, że omawiany zespół należy do największych w zasobie Archiwum Państwowego w Kielcach, liczy bowiem ponad 17000 jednostek archiwalnych. Daty skrajne to lata [1849] 1867-1918 ${ }^{82}$. Akta są spisane oczywiście w języku rosyjskim.

Lwia część kluczowych dla tegoż artykułu materiałów znajduje się w aktach wytworzonych przez Wydział Administracyjny Rządu Gubernialnego Kieleckiego. Dwa obszerne poszyty z lat 1867-1891 stanowią dokumentacje remontów checińskiej fary. Odnaleźć można w nich rachunki kosztów prowadzonych prac re-montowych z lat 50 i 60 XIX w., wykazy cen materiałów budowlanych, kontrakty, kosztorysy, kwity, protokoły posiedzeń komitetu zajmującego sie reparacja. przychody i rozchody, obrachunki. Protokoły rewizyjno-odbiorcze natomiast informują szczegółowo o przeprowadzonych pracach ciesielskich, stolarskich, murarskich, blacharskich i szklarskich, o cenach i rodzaju wykorzystanych materiatów z lat $1857,1858,1861,1867^{83}$. Szczególną uwage zwraca pochodzący z 1854 roku plan sytuacyjny dzwonnicy przy kościele parafialnym w Chẹcinach i widok sygnaturki na tymże kościele ${ }^{84}$. Głównie kosztorysy robót zawiera poszyt $\mathrm{z}$ lat 1890-1891 dotyczący remontu elewacji parafialnej świątyni w Chẹcinach ${ }^{55}$. Jeden z poszytów zwiera także rozkład składek mieszkańców chęcińskiej parafii na remont kościoła $\mathrm{z}$ lat $1893-1895^{86}$. Sprawieniu nowych organów poświęcona jest jedna jednostka ${ }^{87}$, w której zachował się rysunek pozytywu organowego ${ }^{88}$. Istotne znaczenie ma niewatpliwie inwentarz parafii z $1887 \mathrm{r}^{89}$ sporządzony przy okazji przejmowania probostwa przez księdza Józefa Ćwiklińskiego. Kilka jednostek stanowi dokumentację funduszów chęcińskiej parafii ${ }^{90}$. Interesującym poszytem jest Raport dozoru kościelnego parafii Chęciny o zaborze ziemi przynależnej chęcińskiej służbie kościelnej z lat 1868-1871 zawierający odpis konsygnacji realności bractwa św. Anny przy kościele parafialnym w mieście Chęcinach w po-

${ }^{82}$ Wstep do inwentarza zespolu akt Rzqd Gubernialny Kielecki z lat [1810] 1866-1918 [1975], oprac. J. Hładkowa, Kielce 1985; Archiwum Państwowe, s. 53, 54; szerzej zob. też Ł. Guldon, Urzedy administracji ogólnej w guberni kieleckiej w drugiej polowie XIX i poczatkach XX wieku. Dzieje ustrojowe, przepisy kancelaryjne, stan opracowania, wykorzystanie w badaniach regionalnych inaukowych, http://www.archiwa.gov.pl/lang-pl/wydawnictwa/epublikacje/referaty-archiwistow.html

${ }^{83}$ APK, Rząd Gubernialny Kielecki, sygn. 1867, 1868.

${ }^{84}$ Tamże, sygn. 1868, k. 90.

${ }^{85}$ Tamże, sygn. 2899.

${ }^{86}$ Tamże, sygn. 3156.

${ }^{87}$ Tamże, sygn. 3632.2724 , s. $7-41$.

${ }^{88}$ Tamże, k. 41.

${ }^{89}$ Tamże, sygn. 2724.

${ }^{90}$ Tamże, sygn. 1395, 1885, 3156, 3880, 4065, 4356, 4524, 4704. 
wiecie kieleckim z 1802 r. ${ }^{91}$ Nieco inny charakter ma jednostka dotycząca majątku pozostałego po proboszczu Batorskim, w skład której wchodzi inwentarz majątku zmarłego oraz rachunki związane $\mathrm{z}$ leczeniem i pogrzebem kapłana ${ }^{92}$.

Skromne informacje o istniejącej przy parafii w Chęcinach prebendzie św. Anny przynoszą materiały o oddaniu tejże prebendzie w sześcioletnia dzierżawe części ziemi osady pokarczemnej ${ }^{93}$.

Drugą grupę akt stanowi dokumentacja klasztoru panien franciszkanek. I w tym przypadku zachowały się przede wszystkim materiały związane z pracami remontowymi i budowlanymi. Pojedyncze jednostki dotyczą remontu klasztoru z lat $1875-1886^{94}$, remontu ogrodzenia klasztornego i sprawienia nowych wrót z lat $1890-1891^{95}$, remontu klasztornych budynków gospodarczych z lat $1890-1892^{96}$ budowy skrzydła w mieszkalnej części klasztoru z lat $1891-1893^{97} \mathrm{i}$ wreszcie remontu spalonego od uderzenia pioruna dachu na poklasztornym kościele z 1913 roku ${ }^{98}$. Oprócz tego kilka poszytów poświęconych jest sprawom majątku klasztoru franciszkanek ${ }^{99}$. Zachowana dokumentacja obrazuje także sprawę mianowania przeoryszą żeńskiego klasztoru Magdaleny Antoniewicz po śmierci ksieni Kamili Tyżyńskiej ${ }^{100}$ oraz doniesienia Zarządowi Dóbr Państwowych wiadomości o klasztornych gmachach ${ }^{101}$. Z 1883 r. pochodzi plan sytuacyjny nieruchomości należącej do sióstr franciszkanek, na którym kolorem różowym zaznaczono kościół i klasztor, na zielono sad, na źółto zaś dom kapelana ${ }^{102}$. Spis materiałów dotyczących zakonu franciszkanek w Chęcinach zamykają akta ilustrujące sprawę jego likwidacji w 1902 roku $^{103}$.

Zaledwie jedna jednostka archiwalna związana jest $\mathrm{z}$ innym obiektem sakralnym Chęcin - kaplicą więzienną. Zawarte w tym poszycie informacje dotyczą zaopatrzenia kaplicy w sprzęt liturgiczny ${ }^{104}$.

\section{Urząd Wojewódzki Kielecki I (1919-1939)}

Mocą ustawy z 2 sierpnia 1919 r. w odrodzonej Polsce ustanowiono pięć województw. Jednocześnie jako organy ogólnej administracji państwowej II instancji powołano urzędy wojewódzkie, którymi kierowali wojewodowie. Byli oni

${ }^{91}$ Tamże, sygn. 1062

${ }_{92}^{92}$ Tamże, sygn. 2558. Inwentarz znajduje się na stronach 93-102 i 129-134.

${ }^{93}$ Tamże, sygn. 14896

${ }_{94}^{4}$ Tamże, sygn. 1929.

${ }^{95}$ Tamże, sygn. 2898.

${ }^{96}$ Tamże, sygn. 2929.

${ }^{97}$ Tamże, sygn. 2993.

${ }^{98}$ Tamże, sygn. 4734.

${ }^{99}$ Tamże, sygn. 1572, 2920, 2921, 3355.

${ }^{100}$ Tamże, sygn. 3538.

${ }^{101}$ Tamże, sygn. 3742.

${ }^{102}$ Tamże, sygn. 17276.

${ }^{103}$ Tamże, sygn. 3892.

${ }^{104}$ Tamże, sygn. 10524. $\mathrm{z}$ jednej strony reprezentantami rządu, sprawującymi powierzone im funkcje władzy państwowej przy pomocy podległych im urzędów wojewódzkich, a z drugiej szefami administracji ogólnej. Do kompetencji urzędów wojewódzkich należały sprawy administracji państwowej z wyłączeniem sądownictwa, wojskowości, skarbowości, szkolnictwa, kolei, poczty i spraw zastrzeżonych dla urzędów ziemskich ${ }^{105}$

Jednym z nowo utworzonych województw było rozległe województwo kieleckie z Urzędem Wojewódzkim Kieleckim na czele, którego struktura organizacyjna w ciągu dwudziestu lat istnienia ulegała częstym przeobrażeniom. W zespole archiwalnym Urząd Wojewódzki Kielecki ${ }^{106}$ wyróżnić można akta następujących Wydziałów: Prezydialnego, Budżetowo-Gospodarczego, Administracyjnego, Ogólnego, Bezpieczeństwa, Społeczno-Politycznego, Samorządowego, Wojskowego, Zdrowia, Pracy i Opieki, Rolnictwa i Reform Rolnych, Weterynaryjnego, Przemysłowego, Komunikacyjno-Budowlanego, Technicznego czy wreszcie akta Dyrekcji Robót Publicznych i Wojewódzkiego Konserwatora Zabytków. Wspomnieć bez wątpienia wypada, że liczący przeszło 23000 jednostek archiwalnych Urząd Wojewódzki Kielecki I jest największym zespołem Archiwum Państwowego w Kielcach ${ }^{107}$.

Biorąc pod uwagę rozmiar zespołu, to znikoma cześć materiałów wchodzących w jego skład dotyczy przedmiotu niniejszego artykułu. W aktach Wydziału Administracyjnego odnaleziono bowiem jedynie pismo Ministerstwa Wyznań Religijnych i Oświecenia Publicznego do wojewody kieleckiego z dnia 21 maja 1923 r. zatwierdzające uchwałę zebrania parafialnego w Chęcinach z dnia 3 II 1924 r. dotyczącą składek na restauracje świątyni ${ }^{108}$ oraz protokół ogólnego zebrania parafialnego parafii Chęciny z dnia 24 maja 1925 r. 109

Ponadto w części stanowiącej spuściznę aktową Wojewódzkiego Konserwatora Zabytków wspomnieć należy jednostkę archiwalną poświęconą chęcińskim zabytkom. W jej skład wchodzi sześć poszytów, z czego trzy dotyczą obiektów sakralnych: kościoła parafialnego, klasztoru bernardynek (klarysek) i zabudowań należących dawniej do franciszkanów. Zachowana dokumentacja to korespondencja dotycząca prac konserwatorskich prowadzonych w wymienionych wyżej zabytkach wymieniana pomiędzy Urzędem Wojewódzkim Kieleckim a Magistratem miasta Chęcin, względnie innymi organami ${ }^{110}$. W poszycie tyczącym się klasztoru bernardynek uwagę zwraca plan sytuacyjny obiektu'11!

${ }^{105}$ Archiwum Państwowe, s. 68-70.

${ }^{106}$ Zespół Urząd Wojewódzki Kielecki z lat 1919-1939 nazywany jest często Urzędem Wojewódzkim Kieleckim I (UWK I) w odróżnieniu od urzędu o tej samej nazwie działającego w latach 1944-1950 określanego jako Urząd Wojewódzki Kielecki II (UWK II).

107 Wstep do inwentarza zespolu akt Urząd Wojewódzki Kielecki z lat 1919-1939, oprac. R. Guldon, K. Kasperek, Kielce 1980.

${ }^{108}$ APK, Urząd Wojewódzki Kielecki I, sygn. 1359, s. 533.

${ }^{109}$ Tamże, sygn. 1367 , s. 803-821.

${ }^{110}$ Tamże, sygn. 21428.

111 Tamże, s. 221. 


\section{Urząd Wojewódzki Kielecki II (1944-1950)}

Po wyzwoleniu Polski spod okupacji hitlerowskiej przywrócono podział kraju na województwa. Na mapę Polski wróciło w zmienionym nieco kształcie województwo kieleckie. Pod koniec października 1944 r. w Sandomierzu podjał swa działalność Urząd Wojewódzki Kielecki, po czym 22 stycznia 1945 r. przeniósł się do Kielc. Jego organizacja opierała sie na dekrecie PKWN z 21 sierpnia 1944 r. oraz normatywach z okresu dwudziestolecia międzywojennego. Do kompetencji urzędów wojewódzkich należały sprawy administracji państwowej z wyłączeniem sądownictwa, wojskowości, skarbowości, szkolnictwa, kolei, poczty i spraw zastrzeżonych dla urzędów ziemskich. Urząd Wojewódzki Kielecki działał do 1950 r., kiedy to został zlikwidowany, a jego kompetencje przejęło Prezydium Wojewódzkiej Rady Narodowej w Kielcach ${ }^{112}$.

Istniejący w latach 1944-1950 Urząd Wojewódzki Kielecki pozostawił obszerną, bo liczącą blisko 5000 jednostek archiwalnych, spuściznę aktową w postaci zespołu o nazwie Urząd Wojewódzki Kielecki II ${ }^{113}$. Składa sie on z materiałów wytworzonych przez 22 Wydziały: Ogólny, Administracyjny, Samorządowy, Społeczno-Polityczny, Opieki Społecznej, Zdrowia, Kultury i Sztuki, Aprowizacji, Handlu, Przemysłowy, Komunikacji, Pomiarów, Odbudowy, Gospodarki Komunalnej, Budżetowo-Gospodarczy, Personalny, Rolnictwa, Urządzeń Rolnych, Pomiarów Rolnych, Wodno-Melioracyjny, Weterynarii oraz Finansów Rolnych $^{114}$.

Dwie jednostki w aktach Urzędu Wojewódzkiego Kieleckiego II stanowi dokumentacja budynków poklasztornych w Chęcinach. W archiwaliach tych dominują plany gmachu należącego niegdyś do ojców Franciszkanów a następnie zamienionego na więzienie (przekroje, elewacje, rzuty poziome, plany sytuacyjne) ${ }^{115}$ Pozostałe dokumenty to umowa najmu, opis zabudowań poklasztornych, szczegółowy program robót, kosztorys prac adaptacyjnych, umowy dzierżawne ${ }^{116}$.

\section{Prezydium Wojewódzkiej Rady Narodowej w Kielcach \\ Wojewódzki Konserwator Zabytków}

Prezydium Wojewódzkiej Rady Narodowej w Kielcach zostało powołane na mocy ustawy z 20 marca 1950 r. o terenowych organach jednolitej władzy państwowej. Było ono kolegialnym organem wybieranym przez radę i jej podległym, nadzorowało wykonanie uchwał rady. Prezydium jako organ wykonawczy i zarządzający sprawowało funkcje wykonawcze władzy państwowej. Swe zadania wykonywało w oparciu o aparat administracyjny (referaty, wydziały), który bez-

\footnotetext{
${ }^{112}$ Archiwum Państwowe, s. 77-81.
}

${ }^{113}$ Zob. przyp. 106.

${ }^{114}$ Wstep do inwentarza zespolu akt Urzqd Wojewódzki Kielecki II z lat [1925-1939] 1944-1950 [1951], oprac. K. Nobis.

${ }^{115}$ APK, Urząd Wojewódzki Kielecki II (1945-1950), sygn. 213, 228.

${ }^{116}$ Tamże, sygn. 228 pośrednio zarządzał poszczególnymi dziedzinami spraw z zakresu działalności gospodarczej, społecznej i kulturalnej. Prezydium Wojewódzkiej Rady Narodowej w Kielcach zakończyło działalność zgodnie z ustawą z 22 listopada 1973 r. o zmianie ustawy o radach narodowych wraz z powołaniem do życia Urzędu Wojewódzkiego w Kielcach ${ }^{117}$

Rezultatem aktotwórczej działalności Prezydium Wojewódzkiej Rady Narodowej w Kielcach jest zespół o tej samej nazwie. Licząc z górą 17000 jednostek archiwalnych należy do największych zespołów Archiwum Państwowego w Kielcach. Jego zawartość stanowią akta Wydziałów: Organizacyjno-Prawnego, Finansowego, Budownictwa, Urbanistyki i Architektury, Budżetowo-Gospodarczego, Gospodarki Komunalnej i Mieszkaniowej, Gospodarki Wodnej i Ochrony Środowiska, Kultury, Pracyi Pomocy Społecznej,Przemysłowego, RolnictwaiLeśnictwa, Skupu, Statystki, Handlu Zatrudnienia, Zdrowia, Wojewódzką Komisję Planowania Gospodarczego, Urząd Spraw Wewnętrznych oraz akta Wojewódzkiego Konserwatora Zabytków, Wojewódzkiej Komendy Straży Pożarnej i Kuratorium Okręgu Szkolnego ${ }^{118}$.

W zespole Prezydium Wojewódzkiej Rady Narodowej w Kielcach, w części wytworzonej przez Wojewódzkiego Konserwatora Zabytków znajdują się trzy jednostki dotyczące sakralnych obiektów Chęcin. Jeden poszyt poświęcony jest kościołowi parafialnemu. Zawiera on korespondencję w sprawach remontu świątyni, robót zabezpieczających dach, robót elektryfikacyjnych z lat 1951-1958. Z ciekawszych dokumentów wymienić można: Sprawozdanie z ekspertyzy przeprowadzonej $w$ czasie lutego 1958 r. przy polichromii $w$ zabytkowym parafialnym kościele w Chęcinach z dnia 16 III 1959, Sprawozdanie z przeprowadzonych badań stratygraficznych starych tynków i malowidet ściennych z dnia 16 IV $1959 r^{119}$

Znacznie bogatsze są materiały dotyczące zabudowań pofranciszkańskich. Stanowią je: korespondencja w sprawie uruchomienia szkoły kamieniarskiej w wymienionym wyżej gmachu, dokumentacja robót remontowo-adaptacyjnych, protokoły oględzin budynku, protokoły zdawczo-odbiorcze prac przy malowidłach, sprawozdania z przeprowadzonych robót konserwatorskich, ich kosztorysy, rachunki i umowy z lat 1945-1954. Śladem po pomyśle umieszczenia w dawnym klasztorze warsztatów mechanicznych naprawy maszyn Spółdzielni Pracy Usług Kolejowych jest pismo Wojewódzkiego Konserwatora Zabytków z 8 XII 1955, w którym sprzeciwia się on tej formie użytkowania niegdysiejszego obiektu sakralnego. Próbą ratowania pofranciszkańskiego zabytku był list z 1956 r. autorstwa Juliusza Leszczyńskiego i Bohdana Waskiełło do redakcji czasopisma „Turysta" w sprawie roztoczenia opieki nad zabytkami Kielecczyzny. Innym dokumentem jest Uchwała nr 5/56 Miejskiej Rady Narodowej w Chęcinach anulująca uchwałą wcześniejszą w sprawie przekazania omawianego gmachu Kieleckim Zakładom Przemysłu Terenowego. Nowa uchwała przewidywała przeznaczenie budynku na siedzibę Liceum Kulturalno-Oświatowego z Rożnicy. W ślad za tym

${ }^{117}$ Archiwum Państwowe, s. 91, 92.

${ }^{118}$ Tamże, s. 92-96.

${ }^{119}$ APK, Prezydium Wojewódzkiej Rady Narodowej w Kielcach - Wojewódzki Konserwator Zabytków, sygn. 37. 
normatywem w omawianym poszycie występuje korespondencja Wydziału Kultury Prezydium Wojewódzkiej Rady Narodowej z Ministerstwem Kultury i Sztuki w sprawie prac konserwatorskich i adaptacyjnych oraz przygotowania dokumentacji technicznej obiektu, celem ulokowania w nim Liceum KulturalnoOświatowego. Kolejne dokumenty to korespondencja w sprawie zagospodarowania poklasztornego gmachu przez Spółdzielnię Pracy, Produkcji i Usług „Twórczość” w Kielcach (1957), umieszczenia w omawianym obiekcie przetwórni owocowej i przetwórni mięsa (1957-1959), składowania lodu przy północnej ścianie klasztoru przez Chęcińskie Zakłady Spoźywcze Przemysłu Terenowego (1958), ulokowania w gmachu rozlewni octu, domu pracy twórczej artystów plastyków (1958), adaptacji obiektu na schronisko turystyczne oraz przewiezienia zabytkowego XVIII wiecznego ołtarza z kaplicy przyklasztornej do kościoła w Stodołach oraz zabezpieczenia i restauracji kaplicy Św. Leonarda. Warto wspomnieć, że pojedyncze pisma dotyczą także klasztoru bernardynek oraz kościoła w Starochecinach ${ }^{120}$.

Najskromniej przedstawia się poszyt dotyczący klasztoru sióstr bernardynek. Stanowi go jedynie prośba zakonnic o udzielenie subwencji na remont kościoła z 1949 r. wraz z kosztorysem ${ }^{121}$

Pewne informacje dotyczące sakralnych obiektów w Chęcinach kryją się też w ogólnej jednostce dotyczącej zabytków checińskich. Interesujący jest przede wszystkim Protokól lustracji zabytków miasta z 1955 r., który wzmiankuje min. o budynku scholasterii oraz gmachu dawnego kościoła św. Ducha' ${ }^{122}$.

\section{Urząd Wojewódzki w Kielcach (1973-1990)}

\section{Wydział do spraw Wyznań}

Urząd Wojewódzki w Kielcach został reaktywowany na podstawie Rozporządzenia Rady Ministrów z 23 listopada 1973 r. i rozporządzeń z 30 maja 1975 r. w sprawie zasad organizacji urzędów terenowych organów administracji państwowej i w sprawie określenia zadań i uprawnień należących do powiatowych rad narodowych i naczelników powiatów. Kierował nim wojewoda, który był organem wykonawczo-zarządzającym oraz terenowym organem administracji państwowej. Wojewodowie powoływani byli przez Prezesa Rady Ministrów po zasięgnięciu opinii Wojewódzkiej Rady Narodowej w Kielcach. Urząd Wojewódzki w Kielcach funkcjonował do końca grudnia 1998 r. Został zlikwidowany w związku z Ustawą z dnia 24 lipca 1998 r. o wprowadzeniu zasadniczego trójstopniowego podziału terytorialnego państwa. W miejsce dotychczasowego województwa kieleckiego powołano województwo świętokrzyskie z organem zarzadzającym - Świętokrzyskim Urzędem Wojewódzkim w Kielcach ${ }^{123}$.

\footnotetext{
${ }^{120}$ Tamże, sygn. 38 .

${ }^{121}$ Tamże, sygn. 36.

${ }_{122}$ Tamże, sygn. 40.

${ }^{123}$ Notatka informacyjna do spisów zdawczo-odbiorczych zespołu akt Urząd Wojewódzki w Kielcach - Wydzial do Spraw Wyznań z lat [1931] 1973-1990, brw, brm.
}

Obecnie w Archiwum Państwowym w Kielcach znajduje się zaledwie czastka materiałów archiwalnych wytworzonych przez Urząd Wojewódzki w Kielcach. Jak dotychczas przejęte zostały jedynie akta powstałe w wyniku działalności Wydziału Finansowego, Wydziału ds. Wyznań oraz Rady Ekonomicznej przy Wojewodzie Kieleckim.

Doskonałym źródłem do badań nad funkcjonowaniem chęcińskiej parafii w latach 1955-1990 jest dokumentacja wchodząca w skład zespołu Urząd Wojewódzki w Kielcach - Wydział ds. Wyznań. Zachowane materiały wytworzone zostały przez Wydział Wyznań Prezydium Wojewódzkiej Rady Narodowej w Kielcach, Wydział Kultury - Wojewódzkiego Konserwatora Zabytków PWRN w Kielcach, Wydział ds. Wyznań Urzedu Wojewódzkiego w Kielcach, Referat Wyznań Prezydium Powiatowej Rady Narodowej w Kielcach, proboszcza parafi Chęciny. Jest to głównie korespondencja decyzje, zezwolenia dotyczace prac zabezpieczających, remontowych i konserwatorskich w zabytkowych obiektach na terenie parafii Chęciny: kościele parafialnym, zabudowaniach poklasztornychikościele filialnym w Starochęcinach, pozwolenia na zakup materiałów budowlanych, wydawanie talonów na ich zakup. Nieco dokumentów poświeconych jest budowie kostnicy na cmentarzu, instalacji ogrzewania w kościele parafialnym oraz kwestii odprowadzanego przez parafię podatku dochodowego ${ }^{124}$

Kolejna jednostka z lat 1955-1990 stanowi dokumentowy efekt starań prowadzonych przez mieszkańców i parafię Chęciny o zwrot dawnych zabudowań franciszkańskich prawowitym właścicielom ${ }^{125}$. Natrafiono tu na wybór tekstów z księgi hotelu w Chęcinach ${ }^{126}$, petycje mieszkańców Checin do wojewody kieleckiego z prośbą o zwrot zabudowańn ${ }^{127}$, plany sytuacyjne i szczegółowe hotelu w Chęcinach z 1977 r. ${ }^{128}$, rys historyczny, notatki i informacje dotyczace zespołu obiektów poklasztornych w Chęcinach ${ }^{129}$. Lwią cześć omawianej teczki stanowi wymieniana pomiędzy różnymi instytucjami administracji państwowej (Urząd Wojewódzki w Kielcach, Wojewódzka Rada Narodowa, Ministerstwo Kultury i Sztuki) i kościelnej (Przewodniczący Episkopatu Polski, Biskup kielecki i Kuria Diecezjalnaw Kielcach), organamipartyjnymi(Komitet WojewódzkiPZPR wKielcach, Komitet Centralny PZPR w Warszawie), mieszkańcami korespondencja oraz innymi organami (Redakcja Katolickiego Tygodnika „Ład”, Wojewódzkie Przedsiębiorstwo Turystyczne w Kielcach, Zarząd Muzeów i Ochrony Zabytków, NSZZ ,Solidarność” Regionu Świętokrzyskiego w Kielcach).

Kolejna teczka z lat 1951-1985 stanowi dokumentacje starań sióstr bernardynek o uzyskanie zgody na ponowną dzierżawę zabudowań poklasztornych. Przeważa liczna korespondencja w przedmiotowej sprawie (pisma Kurii Diecezjalnej w Kielcach i Zgromadzenia ss. bernardynek do PWRN w Kielcach kierowane do I Sekretarza KC PZPR Edwarda Ochaba, Prezydium Miejskiej Rady Narodowej

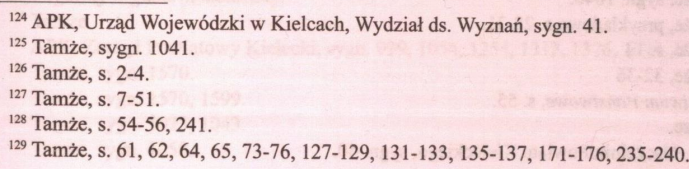


w Chęcinach, Prezydium Powiatowej Rady Narodowej w Kielcach). Zasygnalizowania wymagają także prośby mieszkańców Chęcin do Edwarda Ochaba o przywrócenie praw bernardynkom do nieruchomości (1956 r.). W omawianej jednostce znajdują się też materiały związane z prowadzonymi pracami konserwatorski$\mathrm{mi}^{130}$, informacje i notatki dotyczące zabytkowego obiektu klasztornego, ${ }^{131}$, a także plan budynku ${ }^{132}$. Podanie sióstr bernardynek z 6 X 1978 r. do Naczelnika Miasta i Gmin w Chęcinach zawiera natomiast skróconą historię klasztoru ${ }^{133}$.

\section{Naczelnik Powiatu Kieleckiego}

Postanowieniem Namiestnika Królestwa Polskiego gen. Józefa Zajączka $\mathrm{z}$ dnia 16 stycznia 1816 r. nowo powstałe województwa podzielone zostały na obwody, te zaś na powiaty. W skład województwa krakowskiego z siedziba w Kielcach weszły cztery obwody: kielecki (z powiatami kieleckim i jedrzejowskim), miechowski, olkuski i stopnicki. Na czele każdego z nich stał komisarz obwodu. Na mocy ukazu z 11 października 1842 r. obwody przemianowano na powiaty, a komisarzy obwodów na naczelników powiatów. Naczelnik powiatu, pozostając pod kontrolą gubernatora i rządu gubernialnego, był odpowiedzialny za całość spraw na podległym mu terenie. Czuwał nad dokładnym i terminowym wykonywaniem zarządzeń władz zwierzchnich, był odpowiedzialny za utrzymanie porządku i bezpieczeństwa, sprawował nadzór nad magistratami, zarzadami gminnymi i leśnymi, więzieniami i szpitalami, podejmował decyzje w sprawie skarg i zażaleń. Urząd naczelnika powiatu istniał do końca 1866 i został zlikwidowany $\mathrm{z}$ chwila powołania do życia zarzadów powiatowych ${ }^{134}$

Liczący 206 jednostek archiwalnych zespół Naczelnik Powiatu Kieleckiego stanowi pozostałość aktową po funkcjonującym w latach 1816-1842 komisarzu obwodu kieleckiego oraz urzędującym w okresie 1842-1866 naczelniku powiatu kieleckiego ${ }^{135}$.

W omawianym zespole zaledwie jedna jednostka archiwalna odnosi się do kościoła parafialnego w Chęcinach i zawiera materiały $\mathrm{z}$ lat 1843-1858 dotyczące reparacji światyni. Są to: rachunki prac remontowych, rozkład składek na reparację kościoła z 1852 r., dokumenty dotyczące pożyczek bankowych, liczna korespondencja, opisy ogólne kościoła ${ }^{136}$.

${ }^{130}$ Tamże, sygn. 1040 .

${ }^{131}$ Tamże, przykładowo s. 28-31.

${ }^{132}$ Tamże, s. 14

${ }^{133}$ Tamże, 32-36

${ }^{134}$ Archiwum Państwowe, s. 55.

${ }^{135}$ Tamze.

${ }^{136}$ APK, Naczelnik Powiatu Kieleckiego, sygn. 40.

\section{Zarząd Powiatowy Kielecki}

Utworzona w $1867 \mathrm{r}$. gubernia kielecka podzielona została na siedem powiatów: jędrzejowski, kielecki, miechowski, olkuski, pińczowski, stopnicki i włosz czowski. W myśl „Ustawy o zarządzie gubernialnym i powiatowym w guberniach Królestwa Polskiego" z 31 grudnia 1866 r. powiatami kierowały zarzady powiatowe, które powstały z przekształcenia urzędów naczelników powiatów. Na czele zarządu stał naczelnik powiatu, podległy gubernatorowi i rządowi gubernialnemu. Skład kolegium zarządu oprócz naczelnika stanowili: dwaj pomocnicy naczelnika, lekarz powiatowy i budowniczy powiatowy. Zarząd rozpatrywał sprawy osobowe zarządu powiatowego i innych urzędników w powiecie, sprawy wyposażenia i najmu lokali, budżety i stan kas miejskich, dokonywał rozkładu podatków rządowych, powinności szarwarkowych, składek na ubezpieczenia i utrzymywanie gmin żydowskich, przydzielał zapomogi, ustalał ceny na produkty żywnościowe ${ }^{137}$

Zarzad Powiatowy Kielecki rozpoczał działalność 1 stycznia 1867 r. i funkcjonował do wybuchu I wojny światowej. Jego strukturę organizacyjną tworzyły trzy Wydziały: Ogólny, Administracyjny i Wojskowo-Policyjny. Powstały w efekcie działalności kancelaryjnej Zarzadu Powiatowego Kieleckiego zespół o tej samej nazwie liczy 4019 jednostek archiwalnych i zamyka sie w latach 1866-1915 $5^{138}$ Omawiane akta spisane są w języku rosyjskim.

Akta Zarządu Powiatowego Kieleckiego stanowią cenne źródło do badań nad dziejami miast tegoż powiatu, w tym także Checin. Większość materiałów pozwalających badać historię Kościoła katolickiego na obszarze Chęcin skupiona jest w aktach Wydziału Administracyjnego. Dokumentacja ta obrazuje przede wszystkim kwestie remontów kościoła parafialnego w latach 1867-1869, 18811889 i $1913^{139}$ oraz sprawienia nowych organów ${ }^{140}$. Jest to na ogół korespondencja pomiędzy Zarządem Powiatowym Kieleckim, Rządem Gubernialnym Kieleckim i Dozorem Parafialnym w Chęcinach. Sporadycznie pojawiają się listy składek parafian ${ }^{141}$. Wspomnieć też należy poszyty dotyczące spisania inwentarza kościoła parafialnego, w których jednak same inwentarze nie występują ${ }^{142}$.

Zaledwie cztery jednostki archiwalne traktują o klasztorze franciszkanek. Jeden $\mathrm{z}$ poszytów poświęcony jest klasztornym ogrodom ${ }^{143}$, drugi budowie budyn-

${ }^{137}$ Wstep do inwentarza zespolu akt Kieleckiego Zarzqdu Powiatowego 1866-1915, oprac. B Ryszewski, Kielce brw; Archiwum Państwowe, s. 57, 58; szerzej zob. także Guldon, Urzędy administracji ogólnej w guberni kieleckiej.

${ }^{138}$ Tamże.

${ }^{139}$ APK, Zarzad Powiatowy Kielecki, sygn. 999, 1054, 1254, 1312, 1376, 1599, 2031.

${ }^{140}$ Tamże, sygn. 1570

${ }^{141}$ Tamże, sygn. 1570, 1599.

142 Tamże, sygn. 1023, 1043

${ }^{143}$ Tamże, sygn. 1058 
ków gospodarczych ${ }^{144}$, pozostałe dwa stanowią dokumentacją zamknięcia zakonu $^{145}$.

Listę źródeł do dziejów chęcińskich w zespole Zarząd Powiatowy Kielecki zamykają akta o przejęciu majątku pofranciszkańskiego przez skarb ${ }^{146}$

\section{Starostwo Powiatowe Kieleckie I (1919-1939)}

Rozporządzeniem Rady Ministrów z 28 sierpnia 1919 r. o tymczasowej organizacji powiatowych władz administracyjnych I instancji utrzymany został podział II Rzeczypospolitej na powiaty. Utworzone w 1919 r. województwo kieleckie składało się z 16 powiatów. Jednym z nich był powiat kielecki. Władza w powiatach należała do starostw, którymi kierowali starostowie. Do kompetencji starostw powiatowych należały sprawy administracji państwowej z wyjątkiem sądownictwa, wojskowości, skarbowości, szkolnictwa, kolei, poczty i spraw zastrzeżonych dla urzędów ziemskich ${ }^{147}$

Produktem kancelarii tegoż urzedu jest zespół archiwalny Starostwo Powiatowe Kieleckie $\mathrm{I}^{148}$, złożony $\mathrm{z}$ akt wytworzonych przez 20 referatów: Ogólny, Organizacyjny, Bezpieczeństwa, Porządku Publicznego, Administracyjny, Wyznaniowy, Karny, Wojskowy, Przemysłowy, Wodny, Aprowizacyjny, Samorządowy, Opieki Społecznej, Budżetowo-Gospodarczy, Sanitarny, Weterynaryjny, Ochrony Lasów, Budowlany, Spraw Inwalidów Wojennych, Rolnictwa. Ogółem zespół ten liczy 3792 jednostki archiwalne ${ }^{149}$.

Dla prezentowanej publikacji znacznie maja jedynie akta wytworzone przez Referat Wyznaniowy. Jedna jednostka dotyczy zagospodarowania budynków i gruntów należących dawniej do sióstr klarysek. Zawiera ona sytuacyjny plan zabudowań, plan głównego budynku poklasztornego, plany więzienia w Chẹcinach $w$ języku rosyjskim ${ }^{150}$.W poszycie dotyczącym ochrony zabytków powiatu kieleckiego zachowały sie decyzje Wojewody Kieleckiego o uznaniu za zabytek następujących obiektów znajdujących się w Chęcinach: kościoła parafialnego ${ }^{151}$ kościoła św. Magdaleny ${ }^{152}$, klasztoru sióstr bernardynek ${ }^{153}$. Kolejny poszyt w omawianym zespole to protokół wyboru dozoru kościelnego w Checinach z 1921 r. ${ }^{154}$

${ }^{144}$ Tamże, sygn. 1526

${ }^{145}$ Tamże, sygn. 1844, 2856

${ }^{146}$ Tamże, sygn. 2078.

${ }^{147}$ Archiwum Państwowe, s. 70-72.

${ }^{148}$ Zespół Starostwo Powiatowe Kieleckie z lat 1919-1939 określane jest często jako Starostwo Powiatowe Kieleckie I (SPK I) dla odróżnienia dla urzedu o tej samej nazwie działającego w latach 1944-1950, czyli Starostwa Powiatowego Kieleckiego II (SPK II).

${ }^{149}$ Wstep do inwentarza zespolu akt Starostwo Powiatowe Kieleckie z lat 1919-1939, oprac. R. Guldon, J. Hładkowa, Kielce 1972; Archiwum Państwowe, s. 70-72.

${ }^{150}$ APK, Starostwo Powiatowe Kieleckie I (1919-1939), sygn. 1700.

${ }^{151}$ Tamże, sygn. 1657, s. 138

${ }^{152}$ Tamże, s. 165.

${ }^{153}$ Tamże, s. 174.

${ }^{154}$ Tamże, sygn. 1726
Istotne znaczenie dla badań nad chęcińską parafią w okresie międzywojennym moga mieć protokoły i uchwały zebrań parafialnych z lat 1924-1926. Tam tez znajdują się: taksa pokładnego i rozkład składek na reparację kościoła z 1926 roku $^{155}$. W aktach Starostwa Powiatowego Kieleckiego I odnaleziono także pismo magistratu miasta Chęciny do Starosty Kieleckiego z 1924 dotyczące informacji o zabezpieczeniu chęcińskiego kościoła przed kradzieżą (wyznaczenie dwóch nocnych stróżów) $)^{156}$, korespondencje dotyczaca powołania nowego wikariusza w Chęcinach ks. Jana Śliwakowskiego z 1932 roku $^{157}$ oraz sumaryczne notatki poświecone chęcińskiej świątyni i dozorowi parafialnemu ${ }^{158}$.

\section{Akta miasta Chęciny}

Zespół Akta miasta Chęciny obejmuje 175 jednostek archiwalnych, a jego daty skrajne to lata 1787-1950. Jest to zatem zespół złożony powstały wskutek działania kancelarii kilku organów zarządzających miastem Chęciny w ciągu trzech stuleci. W jego skład wchodza wiec: akta magistratu Checin z przełomu XVIII i XIX wieku, akta Urzędu Municypalnego i Magistratu z lat 1818-1866, Magistratu z lat 1867-1915, Magistratu z lat 1916-1933 i Zarządu Miejskiego z lat 1934-1944 oraz Miejskiej Rady Narodowej i Zarządu Miejskiego z lat 1945$1950^{159}$.

Akta miasta Chęcin stanowią cenne źródło do historii miasta, jego stanu społeczno-ekonomicznego, struktury ludności, gospodarki miejskiej, zabudowy, wyglądu miasta $\mathrm{i}$ jego rozwoju przestrzennego ${ }^{160}$. Niewielkie natomiast znaczenie ma omawiana dokumentacja dla poznania dziejów znajdujących się na terenie miasta kościołów i innych obiektów sakralnych.

Najstarsza jednostka w tym zespole poświęcona świątyni chęcińskiej to akta dotyczące kościoła w Chęcinach i zabudowań plebańskich z lat 1849-1865. Znaleźć w niej można planik sytuacyjny realności donacyjnej $w$ Chęcinach zwanej mury podstarościńskie, plany dwóch domów dla wikariuszy z $1818 \mathrm{r}$., dwa plany plebanii z 1818 r., oszacowanie budowli mieszczqcej w sobie stodoty, stajnie i spichlerze na folwarku należacym do probostwa w Checinach z 1865 r., wyciag z wykazu ubezpieczeń zabudowań miasta Checiny za rok 1849 r. oraz korespondencję dotyczącą zabudowań należących do parafii ${ }^{161}$.

W Aktach miasta Chęciny zachował się też fragment unikatu księgi zmarłych parafii Chęciny za rok 1915 (okładka i 1 karta zapisana dwustronnie w formie tabelarycznej $)^{162}$. Jeden poszyt dotyczy domu opieki w Chęcinach $\mathrm{z}$ lat 1889 -

${ }^{155}$ Tamże, sygn. 1727

${ }^{156}$ Tamże, sygn. 1716, s. 19.

${ }^{157}$ Tamże, sygn. 1717 , s. 47-50.

${ }^{158}$ Tamże, sygn. 1718 , s. 1-8, sygn. 1719 , k. 17v, 18, sygn. 1720, k. 1v, 2.

${ }^{159}$ S. Marcinkowski, Akta miasta Chęcin (1787-1950), w: VII wieków, s. 115-122.

${ }^{160}$ Tamże.

${ }^{161}$ APK, Akta miasta Checiny, sygn. 137.

${ }^{162}$ Tamże, sygn. 150. 
$1904^{163}$. Inna jednostka to $\mathrm{z}$ kolei protokoły wyboru dozoru kościelnego $\mathrm{z}$ lat $1907-1921^{164}$.

\section{Prezydium Miejskiej Rady Narodowej w Chęcinach}

Prezydium Miejskiej Rady Narodowej w Chęcinach utworzone zostało na podstawie ustawy z dnia 20 marca 1950 r. o terenowych organach jednolitej władzy państwowej. Ustawa ta przekształciła rady narodowe w terenowe organy władzy państwowej i likwidowała dualizm władzy rządowej i samorządowej. W myśl ustawy najwyższym organem władzy państwowej na terenie miasta była Miejska Rada Narodowa, która działała za pośrednictwem swych komisji jako ciał opiniodawczych oraz Prezydium jako urzędu wykonawczego. Poszczególne dziedziny działalności powierzone zostały właściwym wydziałom Prezydium. Miejskie Rady Narodowe i ich prezydia miały za zadanie chronić własność społeczna i prawa obywateli, wydawać przepisy prawne w ramach nadanych im przez ustawy oraz wybierać prezydium i komisje rady, uchwalać plany gospodarcze, budżety, stanowić o podatkach i daninach, kontrolować działalność urzędów, przedsiębiorstw i instytucji. Prezydium Miejskiej Rady Narodowej w Chęcinach uległo likwidacji stosownie do ustawy z dnia 22 listopada 1973 r. o zmianie ustawy o radach narodowych oraz Rozporządzenia Rady Ministrów z dnia 23 listopada 1973 roku. W jego miejsce Utworzono Urząd Miasta i Gminy w Chęcinach ${ }^{165}$.

Poszyt zatytułowany Inwentaryzacja budynku poklasztornego przy ul. Matogoskiej $7 w$ Chęcinach $\mathrm{z}$ lat 1965-1966 stanowi jedyny materiał archiwalny związany $\mathrm{z}$ tematem niniejszego artykułu, a znajdujacy się w zespole Prezydium Miejskiej Rady Narodowej w Chęcinach. Jednostka ta składa się z dwóch części. Pierwszą stanowi opis techniczny budynku będącego dawniej własnością franciszkanów. Informuje on m.in. o fundamentach, stropach, więźbie dachowej i dachu, podłogach, stolarce okiennej, schodach, ogrzewaniu oraz oświetleniu. Część druga stanowi plany dawnych zabudowań franciszkańskich. Na potrzeby inwentaryzacji sporządzono plan sytuacyjny obiektów (w skali 1:200), rysunki elewacji południowej i frontowej, przekrój poprzeczny oraz rzuty parteru i pierwszego piętra (w skali 1:100). Inwentaryzację przeprowadził mgr inż. E. Marcinkowski w 1965 r. na zlecenie Zespołu Usług Projektowych przy Wydziale Budownictwa, Urbanistyki i Architektury Prezydium Wojewódzkiej Rady Narodowej w Kiel$\operatorname{cach}^{166}$.

\section{${ }^{163}$ Tamże, sygn. 142. \\ ${ }^{164}$ Tamże, sygn. 64.}

${ }^{165}$ Archiwum Państwowe, s. 98.

${ }^{166}$ APK, Prezydium Miejskiej Rady Narodowej w Chęcinach, sygn. 19; zob. http://checiny. polska.pl/dokumentyarchiwalne/gallery,Inwentaryzacja_budynku_poklasztornego_przy_ul_Malogoskiej_7_w_Checinach_z_30_XI_1965_r_wraz_z_planami_sytuacyjnymi,gid,382107, cid,6202. htm? body $=$ desc

\section{Urząd Miasta i Gminy w Chęcinach}

Urząd Miasta i Gminy w Chęcinach został utworzony na podstawie ustawy $\mathrm{z}$ dnia 29 listopada 1972 r. o utworzeniu gmin i zmianie ustawy o radach narodowych. Zniesiono wówczas dotychczasowy podział terenów wiejskich na gromady, jednocześnie utworzono gminy jako podstawowe jednostki podziału administracyjnego i gospodarczego na terenach wiejskich. Na czele miasta i gminy Chęciny stał Naczelnik Miasta i Gminy Chęciny jako organ wykonawczy Rady Narodowej Miasta i Gminy Chęciny, który realizował swoje zadania przy pomocy aparatu administracyjnego, którym był Urząd Miasta i Gminy. Do zadań Naczelnika Miasta i Gminy należało min. wykonywanie działań związanych z realizacją planu społeczno-gospodarczego kraju, inicjowanie działań związanych z rozwojem społeczno-gospodarczym miasta i gminy, organizacja i koordynacja społecznych sił i środków na rzecz ochrony bezpieczeństwa i porządku publicznego. W ramach Urzędu Miasta i Gminy działały referaty: organizacji, spraw społeczno-administracyjnych, planowania i finansów, rolnictwa i gospodarki żywnościowej, handlu usług, geodezji i gospodarki gruntami, gospodarki komunalnej, budownictwa i ochrony środowiska oraz spraw oświaty, kultury, zdrowia i opieki społecznej. Urząd Miasta i Gminy w Chęcinach zlikwidowano na podstawie ustawy z dnia 8 marca 1990 r. o samorządzie gminnym. W jego miejsce powstał Urząd Miasta i Gminy bęacy organem samorząu terytorialnego ${ }^{167}$.

W 2002 r. Archiwum Państwowe w Kielcach przejęło do swego zasobu zespół Urząd Miasta i Gminy w Chęcinach. Spis zdawczo-odbiorczy tej dokumentacji wskazuje istnienie dwóch jednostek związanych z tematyką niniejszego artykułu. Sa to akta dotyczace spraw wyznaniowych i budownictwa sakralnego $\mathrm{z}$ lat 1977-1988 oraz akta dotyczące przekazania zakonowi S.S. Bernardynek klasztoru przy ul. Małogoskiej $11 \mathrm{w}$ Chęcinach z lat 1978-1985. Jak jednak wynika ze spisu zdawczo-odbiorczego, obie teczki nie zostały jednak przekazane do Archiwum Państwowego w Kielcach, lecz wciąż pozostają w archiwum zakładowym Urzędu Miasta w Chęcinach. Tym samym zespół Urząd Miasta i Gminy w Chęcinach, ze względu na swą tymczasową niekompletność, nie może stanowić podstawy do badań nad dziejami kościoła na terenie miasteczka.

\section{Akta Stanu Cywilnego parafii rzymskokatolickiej w Chęcinach}

Urzędy Stanu Cywilnego zostały wprowadzone w Księstwie Warszawskim Kodeksem Napoleona w 1808 r. Na Kielecczyźnie akta stanu cywilnego zaczęto spisywać od roku 1810 , co wiązało się z przyłączeniem tych terenów do Księstwa Warszawskiego jesienią 1809 roku. Do prowadzenia akt stanu cywilnego zostali zobligowani proboszczowie. Księgi te spisywano w dwóch egzemplarzach. Pierwszy z nich zwany unikatem pozostawał w parafii. Duplikat natomiast stanowiła księga podzielona na trzy części. W każdej z nich osobno zapisywano urodzenia,

\footnotetext{
${ }^{167}$ Informacja archiwalna do ewidencji materialów archiwalnych zespolu akt „Urzq̨d Miasto i Gminy w Chęcinach" 1973-1990, oprac. D. Jaśkowska, bmw, brw.
} 
małżeństwa i zgony. Na ogół dla większości ksiąg sporządzane były skorowidze alfabetyczne urodzonych, zmarłych i zaślubionych. Po upływie roku kalendarzowego duplikaty ksiag stanu cywilnego przekazywano do archiwum hipotecznego przy właściwym terytorialnie Sądzie Pokoju, a od 1842 r. Sądzie Okręgowym ${ }^{168}$ Zasadniczo w Archiwach Państwowych znajdują się więc duplikaty ksiąg urodzeń, małżeństw i zgonów, a w wyjątkowych tylko przypadkach ich unikaty.

Zespół Akta Stanu Cywilnego parafii rzymskokatolickiej w Chęcinach stanowią księgi urodzeń, małżeństw i zgonów z lat 1810-1906 oraz alegata do aktów małżeństw ${ }^{169}$. Ksiegi z lat $1810-1867$ spisane zostały w jezyku polskim, natomiast akta po roku 1868 prowadzono już w języku rosyjskim ${ }^{170}$. Porównując omawiany zespół z aktami stanu cywilnego innych parafii przechowywanymi w Archiwum Państwowym w Kielcach zwrócić uwage należy na zjawisko dość rzadkie, czyli obecność w tymże zespole dokumentacji sprzed 1810 roku. Reprezentują ją trzy księgi stanowiące sumariusze: urodzonych i zaślubionych parafii Chęciny z lat $1726-1810$ oraz zmarłych $\mathrm{z}$ lat $1739-1810^{171}$.

Akta Stanu Cywilnego wykorzystywane są przede wszystkim do poszukiwań genealogicznych. Mogą także stanowić podstawę źródłową badań demograficznych i antroponimicznych nad ludnością danej parafii.

\section{Kielecka Dyrekcja Szkolna}

W poczatkach XIX stulecia w zaborze austriackim nastapił upadek szkół parafialnych. Austriacy w ich miejsce tworzyli szkoły ludowe. Po włączeniu Kielecczyzny w granice Księstwa Warszawskiego władze oświatowe tego państewka rozpoczęły zakładanie szkół elementarnych. Zadaniem tworzenia tego typu placówek zająć miały się towarzystwa szkolne. Opiekę nad szkołami sprawować miały dozory, które stanowiły rodzaj łaczników miedzy społeczeństwem a władzami administracyjnymi. Ustanowiono trzystopniowy rodzaj dozorów. W skład każdego z nich wchodziły osoby duchowne. I tak dozór miejscowy składał się min. z proboszcza, dozór powiatowy z dziekana, dozór departamentowy zaś z biskupa. Po kryzysie oświaty związanym z upadkiem Księstwa Warszawskiego, władze Królestwa Polskiego kontynuowały dzieło zakładania szkół elementarnych. W 1817 r. wprowadzono funkcje organizatora szkół, która w 90\% przypadków sprawowali duchowni. Na podstawie ustawy szkolnej z 1833 r. i rozporządzenia Komisji Rządowej Spraw Wewnętrznych i Oświecenia Publicznego zlikwidowano dozory szkolne w ich miejsce wprowadzono opiekunów, którzy mie-

${ }^{168}$ M. Pawiński, Akta Stanu Cywilnego w Królestwie Polskim w pierwszej polowie XIX w. "Archeion", 106 (2002) s. 203-220.

${ }^{169}$ Alegata czyli załączniki do aktów małżeństw zawierają na ogół odpisy aktów urodzenia bądź metryki chrztów zaślubionych, w przypadku wdowieństwa akty zgonów współmałżonków, wyciąg z księgi ludności, akty znania, itp.

${ }^{170}$ APK, Akta Stanu Cywilnego parafii rzymskokatolickiej w Chęcinach, sygn. 4-195.

${ }^{171}$ Tamże, sygn. 1-3. li sprawować nadzór nad szkołami elementarnymi. Funkcje opiekuna zarezerwowano wyłącznie dla kleru ${ }^{172}$

Od 1864 r. nadzór nad szkolnictwem elementarnym, średnim i realnym sprawowały dyrekcje naukowe. Kielecka Dyrekcja Naukowa obejmowała swoim kompetencjami powiaty kielecki, miechowski, olkuski i stopnicki w guberni radomskiej. W 1867 r. przemianowana została na Kielecką Dyrekcję Szkolną i objęła swym zasięgiem obszar nowo powstałej guberni kieleckiej. Instytucja ta przejęła akta szkolne z pierwszej połowy XIX. W ten sposób powstał zespół archiwalny Kielecka Dyrekcja Szkolna obejmujacy lata [1810] 1864-1917173.

W skład zespołu Kielecka Dyrekcja Szkolna wchodzą dwie jednostki stanowiące dokumentację Szkoły Elementarnej w Chęcinach. W pierwszej z nich znaleźć można min. tabelaryczny Wykaz obejmujacy w sobie opis stanu szkótek parafialnych Elementarnych $i$ ich fundusz $y^{174}$, Protokól zaprowadzenia Towarzystwa Szkótki Elementarnej w parafii chęcińskiej egzystujacej w mieście Chęcinach z 1819 r. ${ }^{175}$, Wykaz protokólu zaprowadzajacego Towarzystwo Szkótki Elementarnej w Parafii Chęcińsskiej z 1822 r. ${ }^{176}$ oraz dość liczne Raporty o uczniach niebędące niczym innym jak arkuszami ocen ${ }^{177}$. Szczególną wartość historyczną mają kopie dwóch przywilejów dla szkoły chęcińskiej, z których pierwszy wydany został przez króla Stefana Batorego, zaś wystawcą drugiego był prymas Stanisław Karnkowski ${ }^{178}$. Drugi poszyt ma charakter bardziej ekonomiczny i zawiera głównie materiały dotyczace dochodów i wydatków szkoły oraz rozkłady składek od mieszkańców Chęcin na utrzymanie Szkoły Elementarnej ${ }^{179}$. Zachowała się też dokumentacja Elementarnej Szkoły Żeńskiej w Chęcinach w postaci etatów dochodu i wydatku funduszów, rozkładów składek i korespondencji ${ }^{180}$

\section{Rada Opiekuńcza Zakładów Dobroczynnych Powiatu Kieleckiego}

Do 1817 r. nadzór nad instytucjami dobroczynnymi w Królestwie Polskim sprawowała Komisja Rządowa Spraw Wewnętrznych. Pierwszą odrębną instytucją o charakterze dobroczynnym była powołana 2 grudnia 1817 r. Rada Ogólna Dozorcza Szpitali. Przy Komisjach Wojewódzkich powstały natomiast podległe jej Rady Szczegółowe, które sprawowały bezpośredni nadzór nad szpitalami. W 1832 r. w miejsce wspomnianych wyżej instytucji utworzono Radę Główną

${ }^{172}$ A. Artymiak, Studia nad historia szkolnictwa elementarnego w obwodach kieleckim i olkuskim województwa krakowskiego (1816-1862), Wrocław, Warszawa, Kraków 1964, passim; W. Caban, Szkolnictwo elementarne na ziemi kielecko-radomskiej (1809-1862), Kielce 1983, passim.

${ }^{173}$ Archiwum Państwowe, s. 51, 113

${ }^{174}$ APK, Kielecka Dyrekcja Szkolna, sygn. 457, s. 4-9.

${ }^{175}$ Tamże, s. 129-133.

${ }^{176}$ Tamże, s. 19, 20.

${ }^{177}$ Tamże, passim.

${ }^{178}$ Tamże, s. $72-75$.

${ }^{179}$ Tamże, sygn. 458

${ }^{180}$ Tamże, sygn. 461 
Opiekuńczą przy Komisji Rządowej oraz Rady Szczegółowe Opiekuńcze przy każdym szpitalu. Rady szczegółowe zarządzały majątkiem danego zakładu lub szpitala, decydowały o przyjecciu pensjonariuszy, o umorzeniu kosztów leczenia, zawierały umowy na dostawy leków i żywności, przygotowywały projekty budżetów rocznych. W roku 1842 powołano natomiast Powiatowe Rady Opiekuńcze Zakładów Dobroczynnych. Sprawowały one nadzór nad dozorami parafialnymi, w których gestii pozostawał zarząd szpitalami, odtąd nazywanymi domami schronienia dla starców i kalek. Rady Powiatowe kontrolowały głównie działalność organizacyjna i finansowa dozorów parafialnych i instytucji dobroczynnych w powiecie. Rada Główna Opiekuńcza i Powiatowe Rady Opiekuńcze zniesiono w 1870 r. powołując jednocześnie Rady Gubernialne oraz Rady Powiatowe Opieki Społecznej ${ }^{181}$

Obejmujący lata 1829-1870 zespół Rada Opiekuńcza Zakładów Dobroczynnych powiatu kieleckiego zawierający 140 jednostek archiwalnych wytworzonych przez różne instytucje o charakterze charytatywnym obszernie informuje o dobroczynności na omawianym obszarze. W zespole tym znaleźć można dwa poszyty dotyczące Chęcin. Zachowały się głównie Rachunki przychodu i rozchodu funduszu szpitala Checińskiego $\mathrm{z}$ lat 1844-1865, kwity i dowody do nich załączone, projekty etatu kasy szpitala $\mathrm{z}$ lat 50 i 60 XIX w., rachunki wydatków na reparację domu schronienia, listy ubogich oraz liczna korespondencja dotycząca funduszu i remontów szpitala ${ }^{182}$. Drugi poszyt dotyczy dzierżawy gruntów chęcińskiego szpitala (korespondencja, akt notarialny i wypis hipoteczny) ${ }^{183}$.

\section{Dyrekcja Ubezpieczeń w Warszawie}

W początku XIX w. na ziemiach polskich powstały pierwsze instytucje ubezpieczeniowe. Na terenie Prus Południowych dla miast z Dyrekcjami w Poznaniu i Warszawie utworzono w 1803 r. Towarzystwo Ogniowe, rok później zaś powołano Towarzystwo Ogniowe dla Wsi. Po likwidacji obu instytucji na obszarze Księstwa Warszawskiego funkcjonowało utworzone w 1807 r. Towarzystwo Ogniowe z Dyrekcja w Warszawie. Natomiast w 1816 r. powołano Towarzystwo Ogniowe dla Miast. Oba Towarzystwa podlegały wspólnej Dyrekcji Generalnej, którą mocą ukazu z dnia 29 XII 1842 r./10 I 1843 r. przekształcono w Dyrekcję Ubezpieczeń. Instytucja ta podlegała Komisji Rządowej Spraw Wewnętrznych i Duchownych. Przy komisjach wojewódzkich pracowali rachmistrze Dyrekcji Ubezpieczeń. Wraz z reformą administracyjną w końcu 1866 r. Dyrekcję Ubezpieczeń zlikwidowano, a jej kompetencje przejęły wydziały ubezpieczeń przy

${ }^{181}$ Wstep do inwentarza zespolu akt Rady Opiekunczej Zakladów Dobroczynnych powiatu kieleckiego i Rady Opiekuńczej Zakladów Dobroczynnych powiatu olkuskiego, oprac. I. Bałabuch, brw bmw; I. Pogorzelska, Instytucje dobroczynne w guberni kieleckiej w drugiejpotowie XLX wieku wświetle źródel archiwalnych, w: ...et quorum pars magna fui... Księga pamiątkowa poświęcona profesorowi Zbigniewowi Janowi Góralskiemu, Kielce 2003.

${ }^{182}$ APK, Rada Opiekuńcza Zakładów Dobroczynnych Powiatu Kieleckiego, sygn. 76

${ }^{183}$ Tamże, sygn. 77. rzadach gubernialnych i zarząach powiatowych. Zadaniem Dyrekcji Ubezpieczeń było ściąganie składek ubezpieczeniowych i wypłacanie odszkodowań. Dokumentacja wytworzona przez omawianą instytucję zawiera zestawienia ogólne informujace o wszystkich ubezpieczonych nieruchomościach oraz szacunki pojedynczych zabudowań. Te ostatnie dostarczają skrupulatnych wiadomości o wyglądzie, stanie zachowania, wymiarach i wartości obiektu oraz o osobie właściciela. Szacunki szczegółowe ponadto informują o materiale $\mathrm{z}$ jakiego wykonane zostały poszczególne części i detale budynku (m.in. okna, drzwi, podłogi) wraz $\mathrm{z}$ ich opisem i wymiarami. Do opisów dołączono ceny robocizny i materiałów budowlanych. Wszystkie te dane składały sie na oszacowaną wartość budynku. Uzupełnieniem szacunków szczegółowych były plany, rysunki budynków, a nierzadko także szkice sytuacyjne lokalizujące nieruchomość w układzie urbanistycznym miejscowości ${ }^{184}$

Znajdujący się w zasobie Archiwum Państwowego w Kielcach zespół Dyrekcja Ubezpieczeń w Warszawie z lat 1822-1866 liczy 1644 jednostki archiwalne. Zachowały sie w nim materiały obrazujace dziewietnastowieczna checińska zabudową, w tym także wykazy i szacunki szczegółowe zabudowań oraz plany sytuacyjne i szczegółowe plebani ${ }^{185}$, kościoła parafialnego ${ }^{186}$, i klasztoru franciszkanek w Chęcinach ${ }^{187}$

\section{Urząd Parafialny w Chęcinach}

Zapewne niewielką czastke materiałów będacych wytworem kancelarii parafialnej w Chęcinach znalazła się w zasobie Archiwum Państwowego w Kielcach tworząc zespół Urząd Parafialny w Chęcinach. Ten niewielki zespół, którego daty skrajne stanowia lata 1856-1939 zawiera jedynie 5 jednostek archiwalnych.

W aktach Urzędu Parafialnego w Chęcinach znalazł się Dziennik ekspedycyjny probostwa, w którym zapisywano dane o korespondencji wychodzacej z parafialnej kancelarii w latach 1856-1860 (wpisy za rok 1856 i 1860 sa niekompletne) ${ }^{188}$. Kolejny poszyt stanowią rozmaite rozporządzenia rządowe i konsystorskie $\mathrm{z}$ lat 1861-1902 w języku polskim i rosyjskim ${ }^{189}$, następny zaś to polsko i rosyjskojęzyczna korespondencja Urzędnika Stanu Cywilnego z lat 1862-1907 dotycząca wydawania kopii i wyciągów akt stanu cywilnego ${ }^{190}$. Analogiczny charakter ma kolejna jednostka z lat 1930-1939 spisana w języku polskim i niemieckim ${ }^{191}$.

${ }^{184}$ Wstęp do inwentarza zespolu akt Dyrekcja Ubezpieczeń z lat 1822-1866, oprac. E. Laszczyk, Kielce 1963. Katalog rysunków architektonicznych z akt Dyrekcji Ubezpieczeń w Wojewódzkim Archiwum Państwowym w Kielcach, oprac. A. Penkalla, J. Szczepański, Warszawa 1993.

${ }^{185}$ APK, Dyrekcja Ubezpieczeń w Warszawie, sygn. 46, s. 17-22.

${ }^{186}$ Tamże, sygn. 47, s. 163-176.

${ }^{187}$ Tamże, s. $85-124$

${ }^{188}$ APK, Urzą Parafialny w Chęcinach, sygn. 1.

${ }^{189}$ Tamże, sygn. 2.

${ }^{190}$ Tamże, sygn. 4

${ }^{191}$ Tamże, sygn. 5 . 
W niewielkiej dutce zapisano z kolei nazwiska ofiarodawców i kwoty datków na reparację kościoła w 1870 r., a także wydatki na wspomniany wyżej cel ${ }^{192}$.

\section{Zbiór dokumentów pergaminowych i papierowych}

Archiwum Państwowe w Kielcach posiada w swym zasobie zbiór dokumentów pergaminowych i papierowych $\mathrm{z}$ lat 1378-1789. Są to materiały zróżnicowane pod kątem proweniencyjnym i tematycznym.

W zbiorze tym znajduje się drugi pod względem starszeństwa znany dokument dotyczący Chęcin a będący w posiadaniu Archiwum Państwowego w Kielcach. Jest nim pergaminowa bulla papieska z 24 stycznia $1648 \mathrm{r}$. o wymiarach 409 x $150 \mathrm{~mm}$. W dokumencie tym papież Innocenty X udziela zupełnego odpustu kościołowi parafialnemu św. Bartłomieja i Trzech Króli w Chęcinach w dni świąt ich patronów. W dolnej części dokumentu znajduje się dopisek stanowiący pozwolenie na ogłoszenie papieskiej decyzji udzielone przez prymasa $i$ arcybiskupa gnieźnieńskiego Macieja Łubieńskiego w dniu 19 grudnia 1648 r. ${ }^{193}$

\section{Więzienie karne w Chęcinach}

Jak już zostało wyżej wspomniane, zabudowania pofranciszkańskie w latach 1817-1927 służyły jako więzienie. Materiały dotyczące jego funkcjonowania w latach do 1915 r. można znaleźć w zespołach Rząd Gubernialny Radomski, Rząd Gubernialny Kielecki, Zarząd Powiatowy Kielecki czy Akta miasta Chęcin. Z lat 1915-1927 pochodzi natomiast zespół Więzienie karne w Chęcinach ${ }^{194}$.

W dokumentacji zachowała się zaledwie jedna jednostka archiwalna, która dostarcza niezwykle skapych wiadomości o prowadzonych w poklasztornym gmachu pracach remontowych ${ }^{195}$.

Kończąc przegląd źródeł do dziejów chęcińskich kościołów w zasobie Archiwum Państwowego w Kielcach należy też podnieść kwestię rozproszenia tego typu archiwaliów. Wiele $\mathrm{z}$ nich znajduje się również $\mathrm{w}$ innych archiwach, w tym przede wszystkim: w Archiwum Diecezjalnym w Kielcach ${ }^{196}$, Archiwum Archi-

${ }^{192}$ Tamże, sygn. 3 .

${ }^{193} \mathrm{APK}$, Zbiór dokumentów papierowych i pergaminowych, sygn. 5; zob. http://checiny.polska. $\mathrm{pl} /$ dokumentyarchiwalne/gallery,Odpust_zupelny_dla_kosciola_parafialnego_sw_Bartlomieja_w Checinach_z_1648_r,gid,315333,cid,6202.htm

${ }_{194}$ Wstepp do inwentarza zespolu akt Więzienie karne w Chęcinach 1915-1927, oprac. R. Guldon, Kielce 1975.

${ }^{195}$ APK, Więzienie Karne w Chęcinach, sygn. 82.

${ }_{196}$ Akta konsystorskie parafii Chęciny, sygn. PC-3/1, PC-3/2, PC-3/3, PC-3/4, PC-3/5, PC-3/6, PC-3/7; Akta parafii Chęciny, sygn. II PC-II/1, II PC-II/2, II PC-II/3, II PC-II/4, II PC-II/5, II PCII/6, II PC-II/7, II PC-II/8; zob. też D. Olszewski, Akta Konsystorza Kieleckiego jako podstawa źródlowa do badań nad parafiami i duchowieństwem pierwszej polowy XIX wieku, „Archiwa Biblioteki i Muzea Kościelne" (dalej: ABMK), 19 (1969) s. 5-30. diecezjalnym w Gnieźnie ${ }^{197}$, Archiwum Diecezjalnym we Włocławku ${ }^{198}$, Archiwum Prowincji OO. Franciszkanów w Krakowie ${ }^{199}$, archiwum zakładowym Urzędu Miasta w Chęcinach, archiwum parafialnym w Chęcinach, Archiwum Głównym Akt Dawnych ${ }^{200}$, Archiwum Państwowym w Radomiu ${ }^{201}$, a także w archiwum kieleckiej Delegatury Instytutu Pamięci Narodowej - Komisji Ścigania Zbrodni przeciwko Narodowi Polskiemu ${ }^{202}$.

Przeprowadzony wyżej przegląd materiałów archiwalnych nie pozostawia watpliwości, że w Archiwum Państwowym w Kielcach przynajmniej w kilkunastu zespołach archiwalnych znajdują się materiały, które wykorzystać można jako źródło do badań nad dziejami Kościoła katolickiego w Chęcinach. Omówione archiwalia odnoszą się w zasadzie jedynie do trzech instytucji kościoła katolickiego znajdujących się w Chęcinach: kościoła pod wezwaniem św. Bartłomieja Apostoła, klasztoru franciszkanów i kościoła pod wezwaniem Wniebowzięcia Najświętszej Marii Panny oraz klasztoru sióstr klarysek (od 1930 r. bernardynek) i kościoła pod wezwaniem św. Marii Magdaleny. Natomiast jeśli chodzi o pozostałe obiekty sakralne, a więc kościół św. Ducha, kaplicę św. Leonarda (do 1927 r. więzienna), kaplicę cmentarna to dotyczace ich informacje są niezwykle skape i fragmentaryczne. Specyfika chronologiczna zasobu Archiwum Państwowego w Kielcach sprawia, że próżno szukać w nim materiałów dotyczących kościoła św. Jakuba, czy kaplicy zamkowej.

Omawiając proweniencję zaprezentowanych powyżej archiwaliów, należy stwierdzić, że jest to dokumentacja wytworzona przede wszystkim przez organa administracji ogólnej szczebla gubernialnego (Rząd Gubernialny Radomski, Rząd Gubernialny Kielecki), a dla XX w. wojewódzkiego (Urząd Wojewódzki Kielecki I, Urząd Wojewódzki Kielecki II, Prezydium Wojewódzkiej Rady Narodowej w Kielcach, Urząd Wojewódzki w Kielcach) oraz szczebla powiatowego

${ }^{197}$ Szerzej zob. M. Aleksandrowicz, J. Rył, W. Zientarski, Archiwum Archidiecezjalne w Gnieźnie, w: Dzieje Poznania i województwa poznańskiego. Informator o materialach archiwalnych, t. 2 , red. C. Skopowski, Warszawa 1982, s. 85-235.

${ }^{198}$ Szerzej zob. S. Librowski, Repertorium wizytacji kanonicznych dawnej archidiecezji gnieźnieńskiej, cz. 1: Akta przechowywane w Archiwum Diecezjalnym we Wloclawku, ABMK 29 (1974)

${ }^{199}$ M. Dębowska, Archiwa kościola katolickiego w Polsce. Informator, Kielce 2002, s. 147.

${ }^{200}$ Przede wszystkim wymienić należy zespół Komisja Rządowa Spraw Wewnętrznych; szerzej zob. Archiwum Glówne Akt Dawnych w Warszawie. Przewodnik po zespolach, zespolach, t. 1 Archiwa Dawnej Rzeczypospolitej, red. J. Karwasińska, Warszawa 1975; Archiwum Glówne Akt Dawnych w Warszawie. Przewodnik po zasobie archiwalnym, t. 2 Epoka porozbiorowa, red. F. Ramotowska, Warszawa 1998; A. Stebelski, Źródla do dziejów ziemi kieleckiej w AGAD w Warszawie, „Pamiętnik Świętokrzyski 1930", Kielce 1931

${ }^{201}$ Archiwalia dotyczące Chęcin zawarte są w następujących zespołach Archiwum Państwowego w Radomiu: Rzad Gubernialny Radomski, Zarzad Rolnictwa i Dóbr Państwowych Guberni Radomskiej, Kieleckiej, Lubelskiej, Siedleckiej; zob. Archiwum Państwowe w Radomiu. Przewodnik po zasobie archiwalnym, red. H. Kisiel, Warszawa 1996.

${ }^{202}$ M. Oziebłowski, A. Szczerba, Oddzial Instytutu Pamięci Narodowej w Krakowie. Delegatura w Kielcach, w: Informator o zasobie archiwalnym Instytutu Pamieci Narodowej (stan na dzień 31 grudnia 2008 roku), red. J. Bednarek, R. Leśkiewicz, Warszawa 2009. 
(Naczelnik Powiatu Kieleckiego, Zarząd Powiatowy Kielecki, Starostwo Powiatowe Kieleckie I). Niezwykle skape materiały zachowały się natomiast w materiałach proweniencji władz miejskich (Akta miasta Chęcin, Prezydium Miejskiej Rady Narodowej w Chęcinach). Niewiele zespołów archiwalnych, których twórcami były organa administracji specjalnej (Kielecka Dyrekcja Szkolna, Dyrekcja Ubezpieczeń, Akta Stanu Cywilnego parafii rzymskokatolickiej w Chęcinach, Rada Zakładów Dobroczynnych Powiatu Kieleckiego). Jedynym zespołem proweniencji kościelnej jest Urzad Parafialny w Chęcinach.

Jeśli chodzi o klasyfikacją chronologiczną będących przedmiotem prezentowanego artykułu materiałów archiwalnych, to bardzo niewiele źródeł do dziejów miasta Chẹcin, jak i znajdujących się w nich świątyń zachowało się z okresu przedrozbiorowego. Sa to jedynie dwa dokumenty pergaminowe, nieco dokumentów w aktach Rządu Gubernialnego Radomskiego oraz sumariusze ksiąg metrykalnych. Znakomicie natomiast udokumentowane sa dzieje kościoła katolickiego w Chęcinach w okresie XIX w., dzięki licznym i obszernym materiałom stanowiących zawartość zespołów Rząd Gubernialny Radomski i Rząd Gubernialny Kielecki, które uzupełniają akta Naczelnika Powiatu Kieleckiego, Zarządu Powiatowego Kieleckiego, a w mniejszym stopniu akta Dyrekcji Ubezpieczeń, Akta Stanu Cywilnego parafii rzymskokatolickiej w Chęcinach i akta Urzędu Parafialnego w Chęcinach. Niewiele informacji w przedmiotowym temacie odnaleźć można w aktach pochodzących z okresu dwudziestolecia międzywojennego, czyli w zespołach Urząd Wojewódzki Kielecki I i Starostwo Powiatowe Kieleckie I. Kwerenda przeprowadzona w zasobie Archiwum Państwowego w Kielcach nie wykazała żadnych archiwaliów z okresu okupacji hitlerowskiej poświęconych chęcińskim świątyniom. Z kolei wnikliwa kontrola kościoła katolickiego przez aparat państwa w dobie Polski Ludowej sprawiła, że dzieje kościoła na terenie Checin w okresie 1945-1990 sa stosunkowo dobrze udokumentowane przez zespół Urząd Wojewódzki Kielecki - Wydział ds. Wyznań.

Omawiana dokumentacja w większości spisana została w języku polskim. Druga grupe stanowia akta rosyjskojezyczne pochodzace z drugiej połowy XIX i początków XX w. (w tym przede wszystkim takie zespoły jak: Rząd Gubernialny Kielecki, Zarząd Powiatowy Kielecki, a częściowo także Akta Stanu Cywilnego i Urzad Parafialny w Checinach). Łacinę reprezentują dwa pergaminy (szesnasto- i siedemnastowieczny) oraz kilka dokumentów w zespole Rząd Gubernialny Radomski. Na materiały spisane w języku niemieckim natrafiono także w aktach Rządu Gubernialnego Radomskiego i Urzędu Parafialnego w Chęcinach.

Wśród zaprezentowanych materiałów przeważa dokumentacja aktowa, wśród której szczególnego zasygnalizowania wymagają dwa pergaminy. Ponadto odnaleziono także nieliczne materiały kartograficzne i rysunki techniczne.

Mówiąc o materiałach archiwalnych do dziejów chęcińskich kościołów przechowywanych w zasobie Archiwum Państwowego w Kielcach nie sposób nie zauważyć, że większość z nich traktuje głównie o budynkach świątyń znajdujących się Chęcinach. Wspomniana dokumentacja począwszy od początku XIX, a na schyłku lat $90 \mathrm{XX}$ stulecia kończąc, informuje przede wszystkim o pracach bu- dowlanych, remontowych, adaptacyjnych ikonserwatorskich prowadzonych wkościele parafialnym św. Bartłomieja Apostoła, kościele i klasztorze sióstr klarysek (od 1930 r. bernardynek) oraz kościele i klasztorze franciszkanów. Dla XIX w. sa to głównie liczne kosztorysy, wykazy wydatków, rachunki, kwity, kontrakty i rozkłady składek parafian na cele reparacji danego obiektu, protokoły rewizyjno-odbiorcze gmachów, dokumentacja dotycząca pożyczek bankowych na prowadzenie robót remontowych. Z okresu XX w. pochodzi dokumentacja o charakterze inwentaryzacyjnym i konserwatorskim (kosztorysy, decyzje, pozwolenia, rachunki, umowy prośby o pożyczki na prowadzenie prac konserwatorskich, sprawozdania, protokoły z przeprowadzonych robót,) oraz liczna korespondencja będąca efektem zabiegów i starań o roztoczenie opieki nad chęcińskimi zabytkami sakralnymi. Druga kategoria materiałów dotyczy spraw ekonomicznych instytucji kościoła katolickiego w Chęcinach. Sa to akta poświęcone zamianie gruntów kościelnych, umowy dzierżaw, fundusze pokładnego, inwentarze kościoła. Nie można też pominać archiwaliów, które powstały jako efekt starań sióstr bernardynek i braci franciszkanów o zwrot kompleksów klasztornych. Wspomnieć też w końcu wypada dokumentacją instytucji silnie jeszcze w XIX w. związanych z kościołem katolickim: szkoły i szpitala w Chęcinach

Podsumowując powyższe rozważania uznać należy, że w zasobie Archiwum Państwowego w Kielcach znajduje się szereg materiałów, które jako uzupełnienie archiwaliów pochodzacych $\mathrm{z}$ innych archiwów, przede wszystkim kościelnych, stanowią cenna podstawe źródłową do badań nad historią stosunków kościelnych w Chęcinach w XIX i XX stuleciu. Szczególne znaczenie omówiona dokumentacja może mieć w kwestii poznania stanu ekonomicznego poszczególnych instytucji checińskiego kościoła katolickiego. Wskazane powyżej materiały dotyczące remontów i prac konserwatorskich poszczególnych obiektów sakralnych służyć mogą również historykom sztuki. Akta Stanu Cywilnego z kolei stanowią istotną bazę dla poszukiwań genealogicznych, demograficznych i antroponimicznych. 